\title{
Lime and phosphogypsum application and sulfate retention in subtropical soils under no-till system
}

\author{
S. Churka Blum¹, E. F. Caires², L. R. F.Alleoni ${ }^{1 *}$ \\ ${ }^{1}$ Department of Soil Science, University of São Paulo, Piracicaba, São Paulo, 13418-900, P.O. Box 9, Brazil , ${ }^{2}$ Department of \\ Soil Science and Agricultural Engineering, University of Ponta Grossa, Avenida General Carlos Cavalvanti 4748, Ponta Grossa, \\ Paraná 84030-900, Brazil. "Corresponding author: alleoni@usp.br
}

\begin{abstract}
This study reports long- and medium-term effects of the application of up to $12 \mathrm{Mg} \mathrm{ha}^{-1}$ of phosphogypsum (PG) as soil conditioner and source of $\mathrm{Ca}$ and $\mathrm{S}$, in two field trials, conducted under no-till systems. One field trial was located in Ponta Grossa, state of Paraná (PR), Brazil, on a loamy Oxisol, which received lime and PG applications in 1993. Another area of study was located in Guarapuava (PR), on a clayey Oxisol,which received PG in 2005. After thirteen years of surface-applied lime on the loamy Oxisol, we observed soil acidity reduction up to $80 \mathrm{~cm}$ depth, while PG effects $\mathrm{Ca}^{2+}$ and $\mathrm{S}_{-} \mathrm{SO}_{4}{ }^{2-}$ contents were more pronounced at deeper soil layers. Sulfate distribution in soil profiles was mostly correlated with $\mathrm{Fe}_{\mathrm{d}}$ and $\mathrm{Fe}_{\mathrm{d}}-\mathrm{Fe}_{\mathrm{o}}$. However, there was no long-term effect of lime and PG additions on no-till maize (Zea mays) and wheat (Triticum aestivum) yields. An appreciable movement of $\mathrm{SO}_{4}{ }^{2-}-\mathrm{S}$ to the subsoil was observed in soil samples from the clayey Oxisol after surface-applied PG. This was observed even in the medium term (3.5 years) and despite the higher adsorption capacity of sulfate. In this case, PG addition had positive benefits on maize and triticale ( $X$ Triticosecale) yields due to the supply of $\mathrm{Ca}^{2+}$ and $\mathrm{SO}_{4}^{-2}-\mathrm{S}$ to the plants.
\end{abstract}

Keywords: sulfur, soil acidity, sulfate adsorption, weathered soil, subsoil acidity, cereal crops

\section{Introduction}

Acidity amelioration is one of the most important strategies in the management of highly weathered soils for an adequate crop growth. Approximately $70 \%$ of the Brazilian cultivated soils are highly acidic, showing toxic levels of aluminum $\left(\mathrm{Al}^{3+}\right)$ and manganese $\left(\mathrm{Mn}^{2+}\right)$, and low availability of exchangeable bases (Ritchey et al., 1982). Therefore, the application of soil amendments is a primary strategy to achieve satisfactory yields in Brazilian agricultural systems.

In such weathered tropical soils, lime and phosphogypsum (PG) are applied as soil amendments to alleviate $\mathrm{Al}^{3+}$ toxicity and improve the root environment, increasing the efficiency of applied nutrients and benefiting crop growth and yield (Toma et al., 1999; Farina et al., 2000a; Caires et al., 2011b). 
Under no-till systems (NTS), soil acidity is alleviated by surface-applied lime (without incorporation), there by maintaining soil aggregation. Nevertheless, in many cases, the amelioration of soil acidity by lime application may be restricted to the first soil layers $(0$ to $10 \mathrm{~cm})$ due to soil conditions and the low mobility of lime products reaction. Subsoil acidity is also one of the major yieldlimiting factors in acid soils (Toma et al., 1999), since it restricts root growth decreasing the exploitation of water and nutrients. Under water deficient situations, the plant roots may need to explore the subsoil layers, thus improving soil layers below the topsoil can be beneficial for grain yield (Ritchey et al., 1980).

Surface-applied $\mathrm{PG}\left(\mathrm{CaSO}_{4} 2 \mathrm{H}_{2} \mathrm{O}\right)$ is an alternative to provide $\mathrm{Ca}$ to crops and to decrease $\mathrm{Al}$ toxicity in soil subsurface layers (Oates and Caldwell, 1985) due to its relative higher solubility $(0.24 \mathrm{~g} / 100 \mathrm{~g}$ $\mathrm{H}_{2} \mathrm{O}$ ) when compared to lime. It is also a source of sulfur (minimum of $16 \% \mathrm{~S}$ ) and provides a long-term residual effect when applied in large amounts, mainly in clayey soils (Toma et al., 1999; Caires et al., 2011b; Blum et al., 2011).

Currently, the recommendation of PG requirements is based on clay content for most Brazilian agricultural soils. Due tothe high operational costs of gypsum application (Toma et al., 1999), high rates of the product are applied in the first year in order to promote long-term effects, especially in clayey soils. However, sulfate and cation losses must be considered for PG applications (Alves and Lavorenti, 2004b). There are many other factors governing sulfate adsorption and leaching. Some of these factors are for example: (i) soil pH (Hue et al., 1985; Zhang and Yu, 1997), (ii) the presence of other anions such as phosphate (Bolan et al., 1988), (iii) the presence of other cations in the soil solution (Chao et al., 1963; Cichota et al., 2007), and (iv) organic matter content (Ensminger, 1954; Couto et al., 1979). The no-till soil surface layer presents unfavorable conditions for sulfate adsorption due to additions of phosphate fertilizers, the surface application of lime and practices that increase soil organic matter content. Therefore, it is important to evaluate the subsoil conditions to measure $\mathrm{SO}_{4}^{-2}-\mathrm{S}$ and cation leaching, especially when high amounts of PG are applied with the aim of achieving long-term effects.

During the 70's and 80's not only the research involving PG was intensified, but also the concern about the use of this phosphoric acid industry's by-product. In those decades many benefits of PG application were brought up, such as the increase of exchangeable $\mathrm{Ca}$, the reduction of exchangeable $\mathrm{Al}$, and the formation of deep rooting in the sub-soil (Reeve and Sumner, 1972; Ritchey et al., 1980; Sumner et al., 1986). A number of field studies have reported about the effects of PG application (Zambrosi et al., 2007; Soratto and Crusciol, 2008; Caires et al., 2011a; b; c). In these studies, however, the depth of sampling was commonly restricted to $60-80 \mathrm{~cm}$, since $90 \%$ of the roots of the main crops are concentrated in this layer. However, there is still a lack of information about long-term of PG effects on the amelioration of sub-soil acidity and ion leaching of top soil.

This study reports long- and medium-term effects of PG applications conducted under a NT System in two field trials. Soil chemical attributes and factors related to $\mathrm{SO}_{4}^{-2}-\mathrm{S}$ permanence in the soil [dithionite extractable $\mathrm{Fe}\left(\mathrm{Fe}_{\mathrm{d}}\right)$, oxalate extractable $\mathrm{Fe}\left(\mathrm{Fe}_{\mathrm{o}}\right)$, oxalate extractable $\mathrm{Al}\left(\mathrm{Al}_{\mathrm{o}}\right), \mathrm{pHNaF}$, remaining $\mathrm{P}$ (Prem) and remaining S (Srem)] were evaluated up to $200 \mathrm{~cm}$ depth. Grain yields of cereal crops Z. mays, T.aestivum and $X$ Triticosecale) were also assessed after PG application of up to $12 \mathrm{tha}^{-1}$.

\section{Materials and Methods}

\subsection{Site description and soils}

The experiments were carried out in two locations of the Brazilian state of Paraná: (i) Ponta Grossa ( $25^{\circ} 10^{\prime} \mathrm{S}, 50^{\circ} 18^{\prime} \mathrm{W}, 794 \mathrm{~m}$ a.s.1.) on a loamy Typic

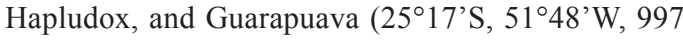
ma.s.l.) on a clayey Typic Hapludox. The state of Paraná is the primary producer of cereals, legumes 
and oil seeds in Brazil, where about 64.1 millions of tons were produced in 2010. This represented $21.6 \%$ of the national production (Brazil, 2011). The oxisols studied are widely distributed across the region and, therefore, are highly representative of the area. Table 1 shows the results obtained from the soil chemical and particle size distribution analyses at $0-20 \mathrm{~cm}$ depth, and some mineralogical attributes of the diagnostic soil horizon at $120 \mathrm{~cm}$ depth.

Table 1. Soil attributes for different depths before the establishment of the experiments.

\begin{tabular}{|c|c|c|}
\hline Attribute & $\begin{array}{c}\text { Typic Hapludox } \\
\text { (Ponta Grossa, Paraná) }\end{array}$ & $\begin{array}{c}\text { Typic Hapludox } \\
\text { (Guarapuava, Paraná) }\end{array}$ \\
\hline & \multicolumn{2}{|c|}{-Surfacelayer $(0-20 \mathrm{~cm})$} \\
\hline $\mathrm{pH}\left(0.01 \mathrm{M} \mathrm{CaCl}_{2}\right)$ & 4.5 & 5.9 \\
\hline${ }^{1}$ Organic $\mathrm{C}\left(\mathrm{g} \mathrm{dm}^{-3}\right)$ & 19 & 28 \\
\hline \multicolumn{3}{|l|}{${ }^{2}$ Exchangeable cations $\left(\mathrm{mmol}_{(+)} \mathrm{dm}^{3}\right)$} \\
\hline $\mathrm{Ca}^{2+}$ & 16 & 48 \\
\hline $\mathrm{Mg}^{2+}$ & 10 & 22 \\
\hline $\mathrm{K}^{+}$ & 1.4 & 4.3 \\
\hline $\mathrm{Al}^{3+}$ & 6 & 0 \\
\hline $\begin{array}{l}\text { Cation Exchange Capacity pH } 7.0(\mathrm{CEC})\left(\mathrm{mmol}_{(+)}\right. \\
\left.\mathrm{dm}^{3}\right)\end{array}$ & 85.4 & 119 \\
\hline P, Mehlich-1 (mg dm $\left.{ }^{-3}\right)$ & 8.9 & 4.7 \\
\hline $\mathrm{SO}_{4}-\mathrm{S}, 0.01 \mathrm{~mol} \mathrm{~L}^{-1} \mathrm{Ca}\left(\mathrm{H}_{2} \mathrm{PO}_{4}\right)_{2}\left(\mathrm{mg} \mathrm{dm}^{-3}\right)$ & 19.1 & 5.9 \\
\hline \multirow[t]{2}{*}{ Soil Texture } & Loamy & Clayey \\
\hline & \multicolumn{2}{|c|}{-Subsurface layer $(\cong 120 \mathrm{~cm})-$} \\
\hline & & \\
\hline $\begin{array}{l}\left.\text { Organic C ( } \mathrm{g} \mathrm{dm}^{-}\right) \\
\mathrm{SiO}_{2}\left(\mathrm{~g} \mathrm{~kg}^{-1}\right)\end{array}$ & $\begin{array}{l}8.1 \\
38\end{array}$ & $\begin{array}{l}10.2 \\
101\end{array}$ \\
\hline $\mathrm{Al}_{2} \mathrm{O}_{3}\left(\mathrm{~g} \mathrm{~kg}^{-1}\right)$ & 144.36 & 294.3 \\
\hline $\mathrm{Fe}_{2} \mathrm{O}_{3}\left(\mathrm{~g} \mathrm{~kg}^{-1}\right)$ & 53.7 & 175 \\
\hline $\mathrm{MnO}\left(\mathrm{g} \mathrm{kg}^{-1}\right)$ & 0.05 & 15.6 \\
\hline $\mathrm{TiO}_{2}\left(\mathrm{~g} \mathrm{~kg}^{-1}\right)$ & 2.1 & 482.4 \\
\hline $\mathrm{Ki}\left(\mathrm{SiO}_{2} / 60\right) /\left(\mathrm{Al}_{2} \mathrm{O}_{3} / 102\right)$ & 0.45 & 0.58 \\
\hline $\mathrm{Kr}\left(\mathrm{SiO}_{2} / 60\right) /\left(\mathrm{Al}_{2} \mathrm{O}_{3} / 102\right)+\left(\mathrm{Fe}_{2} \mathrm{O}_{3} / 160\right)$ & 0.36 & 0.43 \\
\hline Mineralogy (relative distribution) & $\mathrm{Gb}>\mathrm{Kt}>\mathrm{Hm}=\mathrm{Gt}$ & $\mathrm{Gb}>\mathrm{Kt}>\mathrm{Gt}>\mathrm{Hm}$ \\
\hline Kaolinite (\%) & 12.9 & 25.2 \\
\hline Gibbsite (\%) & 26.8 & 37.1 \\
\hline Hematite (\%) & 2.2 & 7.4 \\
\hline Goethite (\%) & 2.9 & 9.9 \\
\hline
\end{tabular}

\footnotetext{
${ }^{1}$.Walkley-Black

2. $\mathrm{Ca}, \mathrm{Mg}$ and $\mathrm{Al}$ extracted by $1 \mathrm{M} \mathrm{KCl}$ and $\mathrm{K}$ extracted by $\mathrm{Mehlich}^{-1}$.

3. Kt (kaolinite), Gb (gibbsite), Hm (hematite), Gt (goethite)
} 
Iron $(\mathrm{Fe})$ and $\mathrm{Al}$ were extracted with $9 \mathrm{M} \mathrm{H}_{2} \mathrm{SO}_{4}$ solution, and $\mathrm{Si}$ was extracted with $\mathrm{NaOH} 30 \%$ (v/v) solution. $\mathrm{Fe}$ and $\mathrm{Al}$ contents were determined by atomic absorption spectrophotometry (AAS), and $\mathrm{Si}$ was quantified by gravimetry (Camargo et al., 1986). It is assumed that the association of $\mathrm{Fe}$, $\mathrm{Al}, \mathrm{Mn}$ and $\mathrm{Ti}$ contents with secondary minerals aresolubilized with $9 \mathrm{M} \mathrm{H}_{2} \mathrm{SO}_{4}$ solution, while $\mathrm{Si}$ is solubilized with $\mathrm{NaOH} 30 \%$ (v/v) solution. Taking these values into consideration, the weathering indexes $\mathrm{Ki}\left(\mathrm{SiO}_{2} / 60\right) /\left(\mathrm{Al}_{2} \mathrm{O}_{3} / 102\right)$ and $\mathrm{Kr}\left(\mathrm{SiO}_{2} / 60\right) /$ $\left[\left(\mathrm{Al}^{2} \mathrm{O}_{3} / 102\right)+\left(\mathrm{Fe}_{2} \mathrm{O}_{3} / 160\right)\right]$ were calculated. A mineralogical analysis of the clay fraction was conducted after treatment with Na-CBD (citratebicarbonate-dithionite) using X-ray analysis of oriented mounts on glass slides. The samples were saturated with either $\mathrm{Mg}$ or $\mathrm{K}$, solvated with glycerol, heated to 350 and $550{ }^{\circ} \mathrm{C}$, and X-rayed. The X-ray diffractograms were obtained in a diffractometer (Philips X'pert System) operating at $40 \mathrm{kV}$ and $40 \mathrm{~m} \mathrm{~A}$ using Ni-filtered $\mathrm{Cu}-\mathrm{K} \alpha$ radiation, at $1.2^{\circ} 2 \theta \mathrm{min}^{-1}$ in the 3 to $45^{\circ} 2 \theta$ range. We also estimated the amounts of minerals, such as kaolinite, gibbsite, goethite and hematite, according to Kämpf and Schwertmann (1983).

Both soils are highly weathered, however, the Typic Hapludox from Guarapuava showed higher amounts of organic carbon, a higher degree of fertility, and no exchangeable Al. Moreover, the Guarapuava soil had a low $\mathrm{Ca} / \mathrm{Mg}$ ratio (Caires et al., 2004) and a lowsulfate content. The Typic Hapludox from Ponta Grossa was highly acidic, with toxic amounts of $\mathrm{Al}^{3+}$ and low amounts of exchangeable bases. Both soils had gibbsite predominance in the clay fraction.

\subsection{Experimental design, treatments and cropping studies}

Before the establishment of the experiment both field sites were cultivated with grain crops under NTS during 15 years. The experiment in Ponta Grossa was established in 1993 on a randomized complete block design with three replications. The plot size was of
$50.4 \mathrm{~m}^{2}(6.3 \times 8.0 \mathrm{~m})$. The treatments consisted of dolomitic lime broadcast on the soil surface at 0 or $6 \mathrm{t}$ ha $^{-1}$ in July 1993, and PG broadcast on the soil surface at 0 or $12 \mathrm{t} \mathrm{ha}^{-1}$ in November 1993. Plots were unlimed or limed. Lime rate was calculated to increase the base saturation in the topsoil $(0-20 \mathrm{~cm})$ to $70 \%$, as shown by Caires et al. (2005), while the PG rate was calculated to achieve the same equivalent in calcium content of the lime treatments. The experiment in Guarapuava was established in September 2005 with PG application at $0,4,8$, and $12 \mathrm{tha}^{-1}$ in a randomized complete block design with four replications. The plot size was of $49.0 \mathrm{~m}^{2}(7.0 \times 7.0 \mathrm{~m})$. The $\mathrm{PG}$ rates were calculated to raise the exchangeable calcium/magnesium $(\mathrm{Ca} /$ $\mathrm{Mg})$ ratio of the topsoil $(0-20 \mathrm{~cm})$ to values between 4 and 8 based on data from previous studies (Caires et al., 1999, 2004). More details concerning to the experimental site in Guarapuava can be found in Caires et al. (2011c).

In Ponta Grossa, Z. mays was sown in October 2008 (15 years after lime and PG applications) at a seeding density of rate of 6 seeds $\mathrm{m}^{-1}$, and a row spacing of 0.85 $\mathrm{m}$ using the hybrid Pioneer 30F53. Cereal grains were harvested from a $10.8 \mathrm{~m}^{2}$ plot. In July 2009 wheat ( $T$. aestivum cv. Supera) was sown at a density of $175 \mathrm{~kg}$ $\mathrm{ha}^{-1}$ and with a row spacing of $0.22 \mathrm{~m}$. The crop was harvested in November 2009 from a $4 \mathrm{~m}^{2}$ plot.

In Guarapuava, maize was sown in September 2008 (Pioneer 30R50) at a seeding rate of 5.5 seeds $\mathrm{m}^{-1}$ with a row spacing of $0.75 \mathrm{~m}$. The harvest was performed in April 2009 from a 8.4-m² plot. In July 2009, triticale (X Triticosecale cv. IPR 111) was sown at a density of $240 \mathrm{~kg} \mathrm{ha}^{-1}$. This crop was harvested in November from a $4 \mathrm{~m}^{2}$ plot. Cereal grain yields were corrected to a moisture of $130 \mathrm{~g} \mathrm{~kg}^{-1}$ and the crop waste was left on the soil surface after the grain harvest.

The yield of cereal plants (maize, wheat or triticale) was evaluated in both areas of study. These cereal plants have shown stronger responses to PG application than leguminous plants as soybean or bean (Raij et al., 1998; Toma et al., 1999; Caires et al., 1999; 2004; 
Table 2. Cropping history and amounts of N, P, and K applied since the establishment of the experiments.

\begin{tabular}{|c|c|c|c|c|}
\hline Agricultural year & Crop & $\mathbf{N}$ & $\mathbf{P}$ & $\mathbf{K}$ \\
\hline \multicolumn{5}{|c|}{$\mathrm{kg} \mathrm{ha}^{-1}$} \\
\hline 1993-1994 & soybean & 0 & 22 & 42 \\
\hline 1994-1995 & maize & 65 & 30 & 33 \\
\hline 1995-1996 & soybean & 0 & 22 & 42 \\
\hline 1996 & wheat & 58 & 27 & 52 \\
\hline 1996-1997 & soybean & 0 & 0 & 40 \\
\hline 1997 & triticale & 60 & 32 & 62 \\
\hline 1997-1998 & soybean & 0 & 0 & 40 \\
\hline 1998-1999 & soybean & 0 & 28 & 54 \\
\hline $1999-2000$ & soybean & 0 & 13 & 25 \\
\hline $2000-2001$ & maize & 132 & 28 & 82 \\
\hline $2001-2002$ & soybean & 5 & 20 & 36 \\
\hline 2002-2003 & soybean & 0 & 23 & 46 \\
\hline 2003 & wheat & 80 & 0 & 33 \\
\hline $2003-2004$ & soybean & 0 & 26 & 50 \\
\hline 2004-2005 & maize & 120 & 40 & 55 \\
\hline $2005-2006$ & soybean & 6 & 36 & 50 \\
\hline $2006-2007$ & soybean & 0 & 22 & 42 \\
\hline $2007-2008$ & soybean & 0 & 26 & 42 \\
\hline 2008-2009 & maize & 134 & 36 & 89 \\
\hline \multirow[t]{2}{*}{2009} & wheat & 80 & 0 & 33 \\
\hline & & & rapu & \\
\hline $2005-2006$ & maize & 195 & 39 & 62 \\
\hline $2006-2007$ & soybean & 0 & 0 & 0 \\
\hline $2007-2008$ & soybean & 5 & 22 & 42 \\
\hline 2008-2009 & maize & 204 & 45 & 94 \\
\hline 2009 & triticale & 66 & 24 & 60 \\
\hline
\end{tabular}

2006; 2011b; c; Farina et al., 2000a; Rheinheimer et al., 2005; Soratto and Crusciol, 2008).

According to the soil test recommendations made for the state of Paraná, the rates of fertilization varied with the type of crop and year in both areas under study (Table 2). Nitrogen, $\mathrm{P}$, and $\mathrm{K}$ were applied most times as urea, triple superphosphate, and potassium chloride, respectively.

Figure 1 shows the seasonal rainfall data observed in both areas under study during crop development. Guarapuava showed a higher mean annual rainfall $(1,922 \mathrm{~mm})$ than Ponta Grossa $(1,554 \mathrm{~mm})$. Ponta
Grossa showed its lower rainfall rate in December 2008 during maize flowering.

\subsection{Soil sampling and chemical analysis}

Soil samples were collected in Ponta Grossa in 2007, thirteen years after PG application. In Guarapuava samples were collected in 2009, three and half years after PG application. Twelve soil core samples per plot were taken with a soil probe sampler to obtain a composite sample of $0-5,5-10$, and $10-20 \mathrm{~cm}$ depths, and five cores of the $20-40$ up to $180-200 \mathrm{~cm}$ depth. 


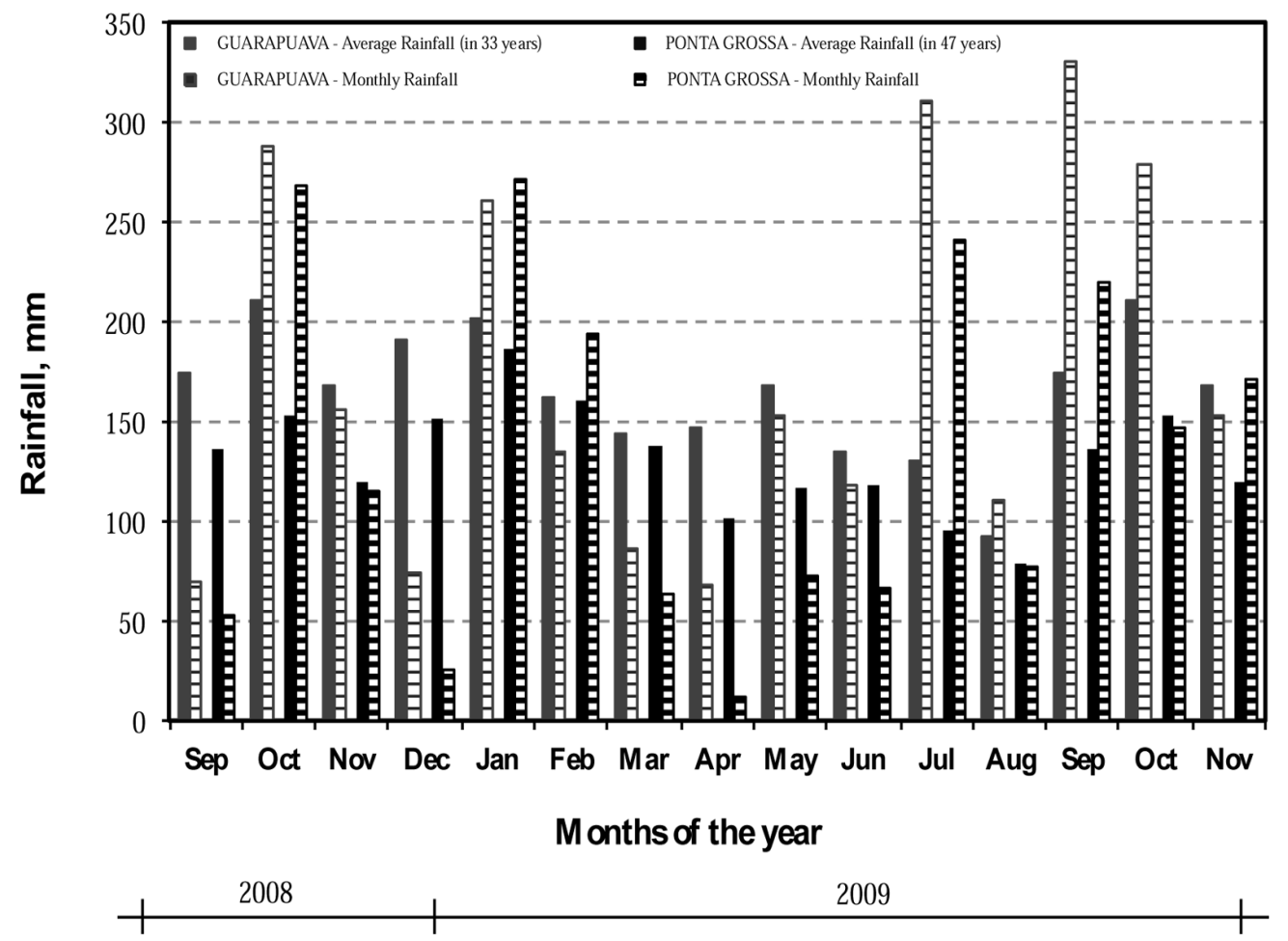

Figure 1. Monthly rainfall registered during the experiments and average monthly rainfall recorded for Ponta Grossa (47 years) and Guarapuava (33 years).

Samples were dried at $40^{\circ} \mathrm{C}$, ground and sieved through a $2 \mathrm{~mm}$ sieve. Then the samples were stored in permeable plastic bags.

To evaluate the chemical alterations over the long and medium term of the treatments at both study sites, the soil $\mathrm{pH}$ was determined. This parameter was measured using $0.01 \mathrm{M} \mathrm{CaCl}_{2}$ suspension and 1:2.5 v/v of soil/ solution. The $\Delta \mathrm{pH}$ was calculated by subtracting the $\mathrm{pH}$ measured in water from the one measured in $1 \mathrm{M}$ $\mathrm{KCl}$ following the methodology proposed by Mekaru and Uehara (1972). The exchangeable $\mathrm{Al}^{3+}$ was extracted using $1 \mathrm{M} \mathrm{KCl}$ solution and determined by titration with $0.025 \mathrm{M} \mathrm{NaOH}$ solution, and $\mathrm{Ca}^{2+}$ and
$\mathrm{Mg}^{2+}$ were also extracted using $1 \mathrm{M} \mathrm{KCl}$ solution. These elements were determined by atomic absorption spectroscopy. The $\mathrm{S}_{-} \mathrm{SO}_{4}{ }^{2}$-soil contents were extracted with $0.01 \mathrm{M}$ calcium phosphate (Fox et al., 1964) in a 1:2.5 (v/v) soil/solution ratio. The suspension used (soil plus extracting solution) was shaken for $30 \mathrm{~min}$, filtered and determined by turbidimetry. The use of calcium phosphate solution was first suggested by Fox et al. (1964), which contains sufficient $\mathrm{P}$ to displace most of the adsorbed sulfate in weathered soils. In selected layers of the control plots (without lime or PG application) adsorption isotherms were built by shaking $2.5 \mathrm{~g}$ of soil with $25 \mathrm{~mL}$ of $\mathrm{CaCl}_{2}$ solutions, which contained $\mathrm{SO}_{4}{ }^{2-}$ added as $\mathrm{K}_{2} \mathrm{SO}_{4}$, for $24 \mathrm{~h}$. After shaking 
the sample, the suspensions were filtered through a filter paper (Whatman $\mathrm{n}^{\circ} 42$ ), and the solutions were analyzed for sulfate content using $\mathrm{BaSO}_{4}$ turbidimetry. The amount of sulfate adsorbed was calculated as the difference between the initial and final sulfate concentrations. The results were fitted to the Langmuir and Freunlich isotherms, widely used for this purpose.

Other chemical attributes were obtained including organic carbon (Walkley Black) and clay content using the densimeter method (Gee and Or, 2002). "Free" iron oxides $\left(\mathrm{Fe}_{\mathrm{d}}\right)$ were extracted using a Na-CBD solution as suggested by Mehra and Jackson (1960). Oxalate-extractable Fe and $\mathrm{Al}$ (which representsthe poorly crystalline oxides) were determined according to methodology proposed by Loeppert and Inskeep (1996). The soil was equilibrated with $0.3 \mathrm{M}$ ammonium oxalate at $\mathrm{pH} 3.25$ on an end-overend shaker. After centrifugation, the concentrations of $\mathrm{Fe}$ and $\mathrm{A} 1$ in the equilibrium solution were measured by atomic absorption spectrophotometry. These forms of $\mathrm{Fe}$ and $\mathrm{A} 1$ have been described as reactive or amorphous and are considered to exert a major influence on the $\mathrm{P}$ sorption capacity of many soils (Singh and Gilkes, 1991). Additionally the $\mathrm{pH} \mathrm{NaF}$ (shaking $0.5 \mathrm{~g}$ of soil for $1 \mathrm{~h}$ with $20 \mathrm{~mL}$ of $1 \mathrm{M} \mathrm{NaF}$ ) was determined following the methodology proposed by Bolland et al. (1996). The index proposed by these authors was created as a quick and economical procedure to access the $\mathrm{P}$ sorption capacity of soils. Thus, the increasing $\mathrm{pH}$ of extracts is an indirect measure of the P sorption capacity of soils (Singh and Gilkes, 1991). The same index was also used by Alves and Lavorenti (2004 a, b), which showed a suitable estimation of sulfate adsorption capacity for weathered sub-soils. The remaining P (Prem) and S (Srem) were obtained following the methodologies proposed by Alvarez et al. (2000) and Alvarez et al. (1983), respectively. The indexes Prem and Srem can also be used to predict $\mathrm{S}$ adsorption capacity, when compared to the $\mathrm{pHNaF}$ The determination of Srem was performed shaking the soil samples with $0.01 \mathrm{M} \mathrm{CaCl}_{2}$, which contained $20 \mathrm{mg} \mathrm{L}^{-1}$ of $\mathrm{S}$ in the proportion 1:10 (soil/solution). The samples were centrifuged and filtered, and the suspension was quantified by turbidimetry.

\subsection{Statistical Analysis}

The effects of soil amendments (in both experiments) on soil chemical attributes and on crop grain yields were analyzed using analysis of variance with a randomized complete block design. Means were compared using Tukey test $(p \leq 0.05)$ for the experiment conducted in Ponta Grossa, and using polynomial regression ( $p$ $\leq 0.05$ ) for the experiment conducted in Guarapuava. We used Pearson product moment to correlate the soil properties with the sulfate retained in the profile. The correlation coefficients were also used to explain increases in crop yield for the Guarapuava experiment.

\section{Results and Discussion}

3.1. Soil chemical attributes - thirteen years after lime and phosphogypsum application on a loamy Oxisol under no-till system

When the soil sampling was performed, after the surface application of lime and PG, the soil samples showed a high acidity and low $\mathrm{pH}$ values at all depths evaluated (Figure 2). Higher $\mathrm{pH}$ values were observed from 0-80 $\mathrm{cm}$ for the treatments that received lime application, either with or without PG. The effects of surfaceapplied lime in alleviating soil acidity below the point of placement have been reported in many field studies under NT S (Caires et al., 2005; 2008; 2011b; Soratto and Crusciol, 2008) and these effects have been attributed to the benefits brought with the adoption of NTS, such as the use of plant debris on the soil surface (Miyazawa et al., 2002; Franchini et al., 2003) and the improvement in soil aggregation and aggregate stability (Six et al., 1999). The aggregation improvement allows to the fine particles of surface-applied lime to move into and down of the profile along with water infiltration to alleviate the sub-soil acidity (Amaral et al., 2004). Regardless of the mechanism involved, surface lime application is in many cases as effective as the incorporation of lime to reduce the sub-soil acidity in variable charge soils (Caires et al., 2011b). 


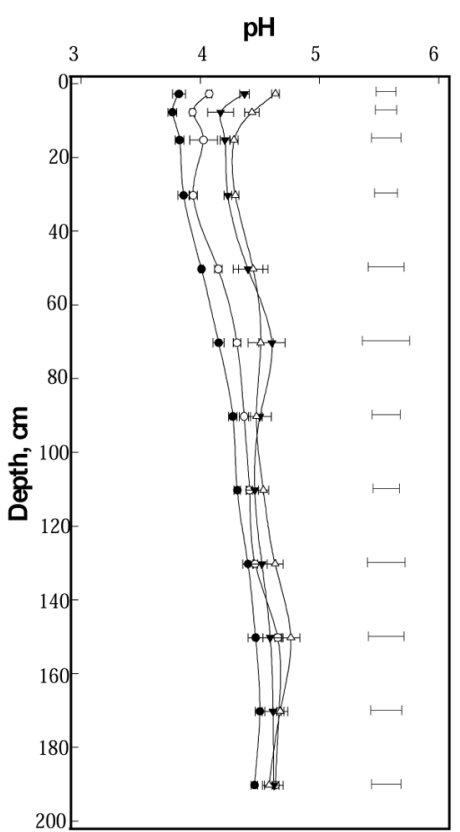

Exchangeable $\mathrm{Ca}^{2+}\left(\mathrm{mmol}_{\mathrm{c}} \mathrm{kg}^{-1}\right)$

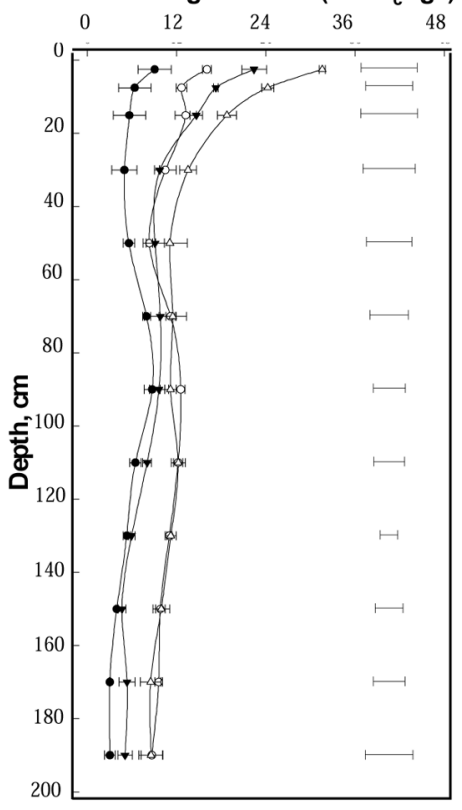

$\Delta \mathrm{pH}$

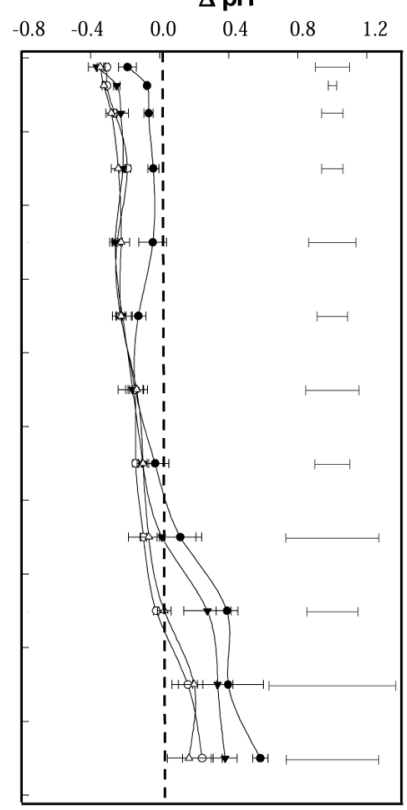

Exchangeable $\mathrm{Mg}^{2+}\left(\mathrm{mmol}_{\mathrm{c}} \mathrm{kg}^{-1}\right)$

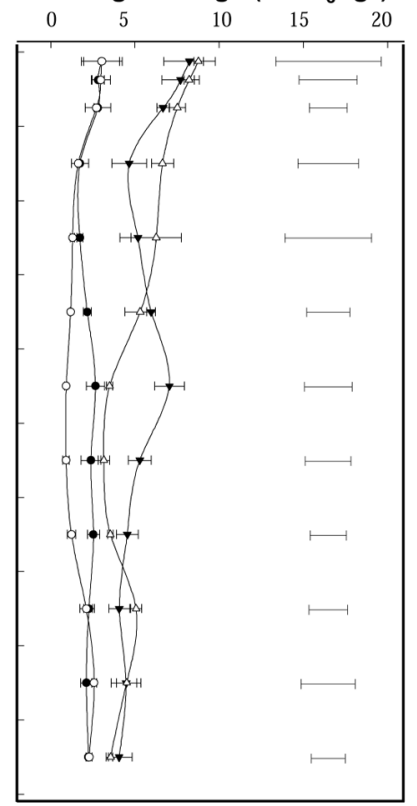

Extractable $\mathrm{S}_{-} \mathrm{SO}_{4}{ }^{2-}\left(\mathrm{mg} \mathrm{kg}^{-1}\right)$
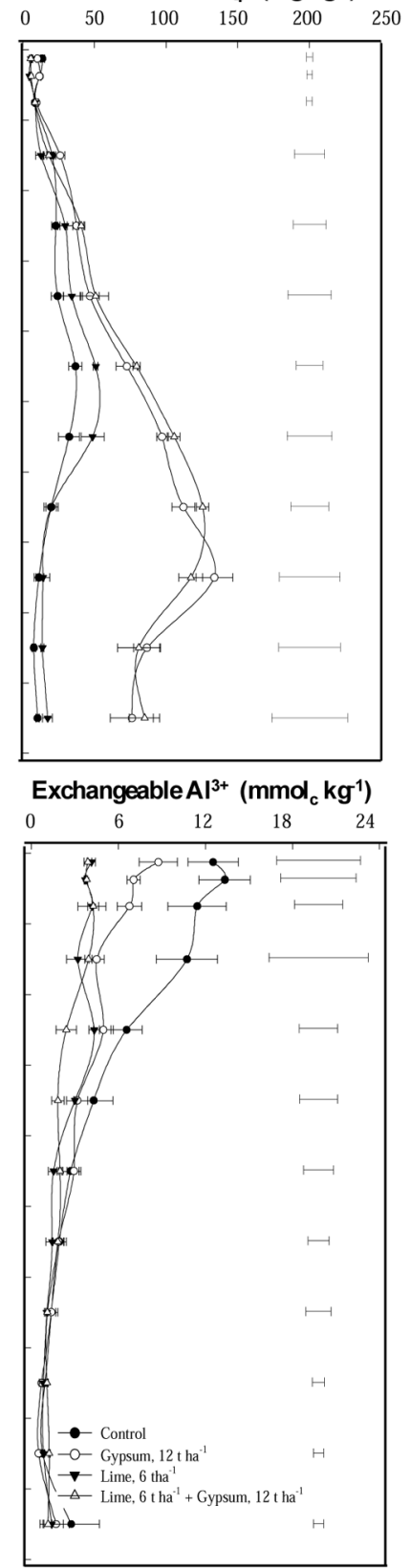

Figure 2. Effects of surface applied lime and phosphogypsum on soil attributes at different depths, 13 years after application. The bars at each depth indicate the LSD at $p=0.05$. 
The main effects of the treatments on acidity alleviation were observed up to $80 \mathrm{~cm}$ depth, and the soil $\mathrm{pH}$ of the plots that did not receive any amendment (control) was higher in the sub-soil than on the surface. This can be explained by the acidification caused by the use of high rates of $\mathrm{N}$ fertilizers (Table 2). Soils of the humid tropics used for grain cropping under NTS have become more acidic because of the use of increased rates of ammonium-based $\mathrm{N}$ fertilizers to obtain more intensive production of cereal crops, like wheat and maize (Juo et al., 1995; Caires et al., 2005; Garbuio et al., 2011). In sub-surface soil samples (120$140 \mathrm{~cm}$ ), slight increases in $\mathrm{pH}$ were observed in the plots that received PG. This increase can be attributed to the adsorption of sulfate on the surface of $\mathrm{Fe}$ and Al oxides, displacing $\mathrm{OH}^{-}$and thus promoting partial neutralization of soil acidity (Reeve and Sumner, 1972). This is called "self-liming effect", and was also reported by Toma et al. (1999) and Farina et al. (2000b).

The $\Delta \mathrm{pH}$ (Figure 2) could be used to predict net soil charge (Mekaru and Uehara, 1972), which was affected by lime and PG application. Up to $80 \mathrm{~cm}$ depth, the soil profile had a negative $\Delta \mathrm{pH}$ since management strategies employed in the area - like liming, fertilizer application, and conservation agriculture (preserving crop residues on the soil surface and increasing contents of soil organic matter) interfere with variable charge soils increasing the net negative charge. At depths greater than $120 \mathrm{~cm}$ we observed the dominance of positive charges, due to high amounts of $\mathrm{Fe} / \mathrm{Al}$ oxides and lower content of organic matter (Table 1). In such layers, a $\Delta \mathrm{pH}$ displacement (to the left region of the figure) was observed with the application of $\mathrm{PG}$, due to the sulfate adsorption mechanism reported by Reeve and Sumner (1972). Lime effects on $\Delta \mathrm{pH}$ were observed up to $80 \mathrm{~cm}$ depth.

After thirteen years of $\mathrm{PG}$ application, sulfur $\left(\mathrm{SO}_{4}{ }^{2-}\right.$ -S) extracted by calcium phosphate was more concentrated at 100-160 $\mathrm{cm}$ depth (Figure 2). The lime application in 1993 increased the $\mathrm{SO}_{4}$-S leaching due to increases in $\mathrm{pH}$.This effect promotes more negative charge and subsequent sulfate repulsion. A previous study that evaluated the same experiment after eight months of PG application showed that approximately $60 \%$ of the $\mathrm{SO}_{4}-\mathrm{S}$ supplied by $\mathrm{PG}$ and extracted by $0.5 \mathrm{M}$ ammonium acetate in $0.25 \mathrm{M}$ acetic acid had leached to depths lower than $60 \mathrm{~cm}$ (Caires et al., 1998). We choose to use the extractant $0.01 \mathrm{M}$ $\mathrm{Ca}\left(\mathrm{H}_{2} \mathrm{PO}_{4}\right)_{2}$ proposed by Fox et al. (1964), because it has enough phosphate to displace most of the adsorbed sulfate in many soils, and because we worked with highly weathered soils samples. Under the conditions previously described, the Ca can keep the ionic strength of the solution, and also depress the extraction of soil organic matter eliminating all possible contamination from the extractable organic S (Beaton et al., 1968). At lower depths (between 120-160 cm), the higher sulfate adsorption persisted for many years after PG application, which could be attributed to the positive charges (as showed by $\Delta \mathrm{pH}$ - Figure 2) attracting the negative charged sulfate ions. This result agrees with those observed by Farina et al. (2000b), who attributed the retardation of PG movement to the reversion of electric charge in sub-surface layers of an Ultisol in South Africa, as reflected by differences in $\Delta \mathrm{pH}$. In this study, part of this behavior could be attributed to the increases in clay content at deeper soil layers, which can be associated to the minerals present in the area (Table 1). Because of the solubility of PG and the soil texture, we would have expected that after thirteen years of application, it would have been completely leached from the soil profile.

We observed effects of the treatments on exchangeable $\mathrm{Ca}$ and $\mathrm{Mg}$ distribution in the entire soil profile (Figure 2). The higher increases of exchangeable $\mathrm{Ca}$ content in both surface and sub-surface layers were observed when lime + PG were applied. The surface application of lime in 1993 showed a residual effect up to $100 \mathrm{~cm}$ depth, while Ca movement up to $200 \mathrm{~cm}$ depth. These results were verified in plots that received PG. Increases in exchangeable $\mathrm{Ca}$ content due to PG application have been frequently reported (Toma et al., 1999; Farina et al., 2000b ; Caires et al. 2004; 2006; 2011c), since each ton of PG provides around $5 \mathrm{mmol}_{\mathrm{c}} \mathrm{dm}^{-3}$ of this nutrient. 
However, the duration of the effect varies with the amount of product applied to the soil and the soil texture. In this experimental area, a previous study reported fast leaching of $\mathrm{Ca}^{2+} 24$ months after PG application, where $40 \%$ of the applied $\mathrm{Ca}^{2+}$ had leached below $80 \mathrm{~cm}$ depth (Caires et al., 2001).

There was an increase in exchangeable $\mathrm{Mg}$ content withthe surface application of lime up to $100 \mathrm{~cm}$ depth (Figure 2). It was also observed a $\mathrm{Mg}^{2+}$ leaching at 80-120 cm depth when the combination of lime + PG wasapplied. After 13 years of PG application we were not able to see an effect of this amendment on the contents of exchangeable Mg. In the same experiment, higher losses of $\mathrm{Mg}^{2+}$ were reported even only twelve months after liming and eight months after PG application (Caires et al., 1998). Moreover, the application of lime increased the $\mathrm{Mg}^{2+}$ levels in the soil solution making it very susceptible to leaching. At eight months after application of PG at $12 \mathrm{tha}^{-1}$,exchangeable Mg contents were higher than those observed in this study (around $10 \mathrm{mmol}_{\mathrm{c}} \mathrm{dm}^{-3}$ in the control plots and $30 \mathrm{mmol} \mathrm{dm}^{-3}$ in the ones that had received lime application). In a longterm experiment, losses of exchangeable $\mathrm{Mg}$ from the surface layers caused by PG application were relatively small when compared to the application of lime alone. These findings support the results obtained for Caires et al. 2011b.

We also observed toxic levels of $\mathrm{Al}^{3+}$ up to $100 \mathrm{~cm}$ depth, except for those treatments that received lime application (Figure 2). Exchangeable $\mathrm{Al}$ is responsible for the harmful effects of soil acidity due that this element is released in low $\mathrm{pH}$ conditions. On the other hand, the increases of $\mathrm{pH}$ due to lime application (Figure 2) caused hydrolysis of the $\mathrm{Al}$ ions, reducing their toxicity. It is important to mention that even after long-term applications it was possible to observe the effects of soil amendments on exchangeable $\mathrm{Al}^{3+}$ reduction up to 80 $\mathrm{cm}$ depth. Below this layer, Al contents were smaller than those observed in samples from the surface layer. The combined surface application of lime and PG under NTS was effective in maintaining the exchangeable Al at non-toxic levels for crops over the long term.
3.2. Soil chemical attributes - 3.5 years after phosphogypsum application on a clayey Oxisol, under no-till system

Surface-applied PG in 2005 did not affect the values of soil $\mathrm{pH}$ of samples collected in 2009, which were measured in $0.01 \mathrm{M} \mathrm{CaCl}_{2}$ up to $60 \mathrm{~cm}$ depth (Figure $3)$. The lack of effect of PG on soil acidity was expected because PG is a neutral salt that does not have the ability of consume $\mathrm{H}^{+}$protons. Conversely, a linear increase in $\mathrm{pH}$ was observed at the lower depths (from 60 to $200 \mathrm{~cm}$ ) as a response to $\mathrm{PG}$ rates, which can also be attributed to the self-liming mechanism previously reported by Reeve and Sumner (1972). It is note worthy that this increase in $\mathrm{pH}$ due to surface PG application was of small magnitude, and the soil utilized in this study had a relatively low acidity for a highly weathered soil. Consequently, very small amounts of exchangeable Al were found through out the investigated soil profiles (Figure 3).

The soil presented net negative charge (represented by $\Delta \mathrm{pH}$ ) up to $80 \mathrm{~cm}$ depth. Below this depth, the remaining charge was found to be predominantly positive. The effect of PG in the soil net charge took place from 80 to $200 \mathrm{~cm}$, reducing the $\Delta \mathrm{pH}$ (Figure 3). Differences between PG-treated and control plots in terms of $\Delta \mathrm{pH}$ lend to support the important role played by $\mathrm{SO}_{4}^{2-}$ sorption-precipitation reactions, where the $\Delta \mathrm{pH}$ differentials are clearly related to the quantities of $\mathrm{SO}_{4}$ held in the soil, as found by Farina et al. (2000b). After the application of PG rates, the content of sulfate extracted with monocalcium phosphate increased in most depths evaluated $(p \leq$ 0.05 ) (Figure 3). In most part of the profile where the samples were taken, the soil samples showed high clay content $\left(700 \mathrm{~g} \mathrm{~kg}^{-1}\right)$. Unlike to the soil of the first experiment, however, which was also discussed in this review, the levels of $\mathrm{Fe}_{\mathrm{d}}$ were constant along the profile (Table 3), and the prevalence of sulfate in the lower depths can be linked primarily to the effect of organic matter. This fact generated negative charges and promoted repulsion of the anions that moved to lower depths. 

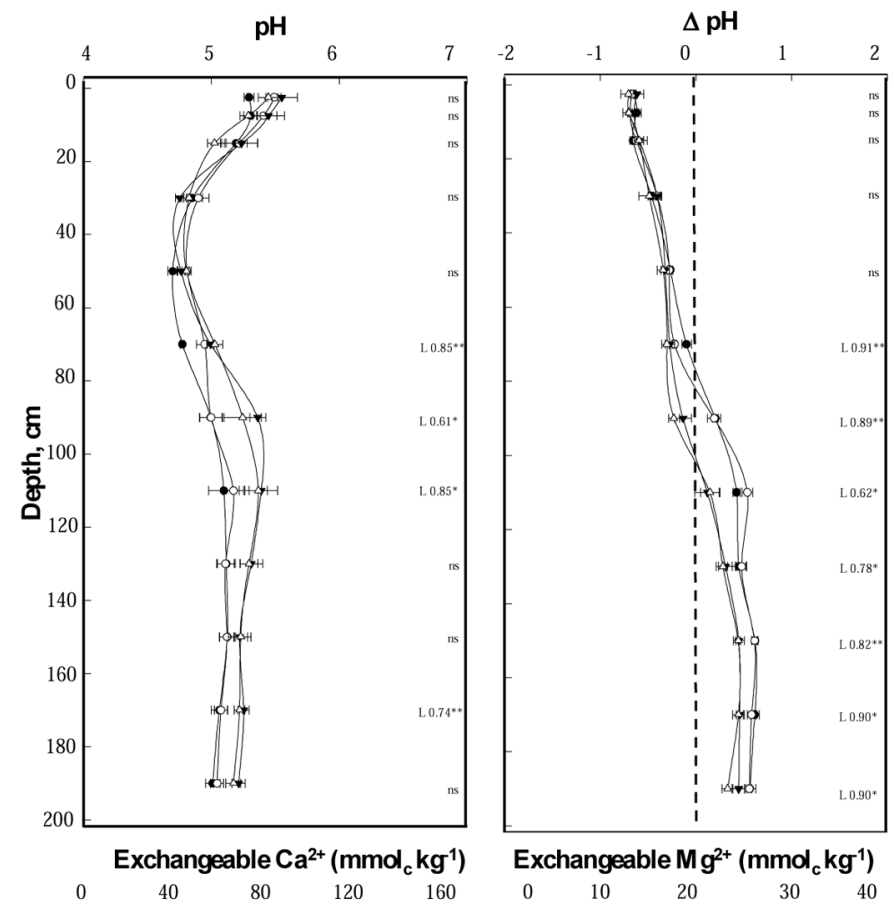

\section{Extractable $\mathrm{S}_{-} \mathrm{SO}_{4}{ }^{2-}\left(\mathrm{mg} \mathrm{kg}^{-1}\right)$}
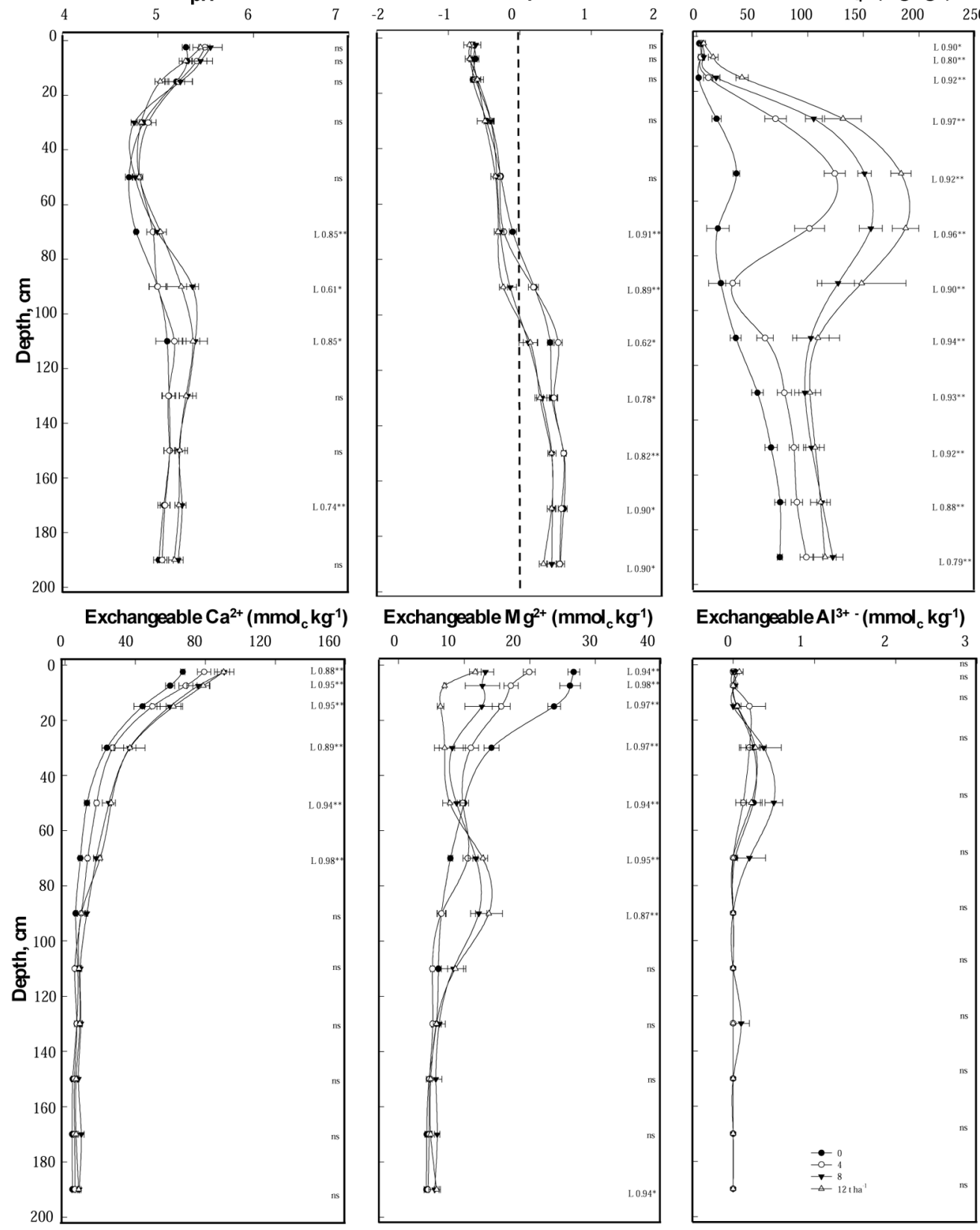

Figure 3. Effects of phosphogypsum rates on soil attributes at different depths, 3.5 years after application. $\mathrm{L}=$ significant by linear regression; ${ }^{*} p \leq 0.05 ; * * p \leq 0.01 ; \mathrm{ns}=$ not significant. 
Table 3. Soil attributes related to sulfate adsorption.

\begin{tabular}{|c|c|c|c|c|c|c|c|}
\hline Depth (cm) & Srem & Prem & OrganicC & $\mathrm{Fe}_{\mathrm{d}}$ & $\mathrm{Fe}_{0}$ & $\mathrm{Al}_{0}$ & $\mathrm{pH} \mathrm{NaF}$ \\
\hline & \multirow{2}{*}{\multicolumn{2}{|c|}{------mg L }} & - & $\mathrm{g} \mathrm{kg}^{-1}$ & & $-\cdots$ & \\
\hline & & & \multicolumn{4}{|c|}{ LVd - Ponta Grossa/PR } & \\
\hline $0-5$ & 14.9 & 21.9 & 23.6 & 36.2 & 1.7 & 3.9 & 9.5 \\
\hline $5-10$ & 14.7 & 18.0 & 19.3 & 38.0 & 1.7 & 3.5 & 9.8 \\
\hline $10-20$ & 14.8 & 15.7 & 17.4 & 37.3 & 1.9 & 4.4 & 9.9 \\
\hline $20-40$ & 12.2 & 13.2 & 14.6 & 42.0 & 1.6 & 4.6 & 10.0 \\
\hline $40-60$ & 10.6 & 8.7 & 11.6 & 45.9 & 1.5 & 4.7 & 10.3 \\
\hline $60-80$ & 10.0 & 7.0 & 10.9 & 46.2 & 1.4 & 6.1 & 10.4 \\
\hline $80-100$ & 9.4 & 5.1 & 10.4 & 47.5 & 1.4 & 5.8 & 10.5 \\
\hline $100-120$ & 7.7 & 3.9 & 9.2 & 50.8 & 1.6 & 6.0 & 10.5 \\
\hline $120-140$ & 6.5 & 2.8 & 8.1 & 50.1 & 1.6 & 4.7 & 10.6 \\
\hline $140-160$ & 4.8 & 1.6 & 7.4 & 49.8 & 1.6 & 4.8 & 10.5 \\
\hline $160-180$ & 4.2 & 1.3 & 8.2 & 48.3 & 1.5 & 3.6 & 10.4 \\
\hline \multirow{2}{*}{$180-200$} & 4.1 & 1.4 & 7.4 & 49.4 & 1.6 & 4.7 & 10.5 \\
\hline & \multicolumn{7}{|c|}{ LVd - Guarapuava/PR } \\
\hline $0-5$ & 15.0 & 2.5 & 44.2 & 168.0 & 5.2 & 10.7 & 10.3 \\
\hline $5-10$ & 13.6 & 1.7 & 33.4 & 172.7 & 4.9 & 9.6 & 10.5 \\
\hline $10-20$ & 12.3 & 1.4 & 29.4 & 167.6 & 5.1 & 9.6 & 10.6 \\
\hline $20-40$ & 9.2 & 1.4 & 25.1 & 173.1 & 5.2 & 11.7 & 10.8 \\
\hline $40-60$ & 6.3 & 0.7 & 20.2 & 164.9 & 5.3 & 12.0 & 10.9 \\
\hline $60-80$ & 4.7 & 0.5 & 17.7 & 165.3 & 5.8 & 13.7 & 11.0 \\
\hline $80-100$ & 3.6 & 0.3 & 14.3 & 166.1 & 5.8 & 10.3 & 11.0 \\
\hline $100-120$ & 3.7 & 0.1 & 11.4 & 173.1 & 6.1 & 10.4 & 10.9 \\
\hline $120-140$ & 3.8 & 0.2 & 10.2 & 168.8 & 6.2 & 10.1 & 10.9 \\
\hline $140-160$ & 3.5 & 0.1 & 8.7 & 172.7 & 6.0 & 9.5 & 10.9 \\
\hline $160-180$ & 3.7 & 0.1 & 7.3 & 179.8 & 6.0 & 9.2 & 10.9 \\
\hline $180-200$ & 3.7 & 0.1 & 7.3 & 192.7 & 6.0 & 8.5 & 10.8 \\
\hline
\end{tabular}

Since the values of $\Delta \mathrm{pH}$ were zero or positive in the subsurface layers (Figure 3), combined with higher amounts of $\mathrm{Al}_{2} \mathrm{O}_{3}$ and $\mathrm{Fe}_{2} \mathrm{O}_{3}$ (175.0 and $294.3 \mathrm{~g} \mathrm{~kg}$ ${ }^{1}$, respectively) and lower $\mathrm{Ki}$ and $\mathrm{Kr}$ (Table 1), we can assume that the soil had reached an advanced degree of weathering. Under these circumstances, $\mathrm{SO}_{4}^{2-}-\mathrm{S}$ was rapidly leached to the sub-soil layers. Sulfate movement is dependent on the particle size distribution of the soil, the intensity of the rainfall after application, the amount of S supplied, and the presence of organic matter and other ions. In this case, the movement of sulfate in the soil profile can be attributed to the low soil acidity (Figure 3) and high levels of organic C (Table 1), as well as fertilization with $\mathrm{P}$ (Table 2), especially in the first layers of the soil.

We found a linear increase in exchangeable Ca content up to $80 \mathrm{~cm}$ depth and leaching of exchangeable $\mathrm{Mg}$ up to $120 \mathrm{~cm}$ depth after application of PG rates (Figure 3). When high rates of $\mathrm{PG}$ were applied to clayey soils, the effects of increasing contents of $\mathrm{Ca}$ in the profile were very durable. In Georgia (USA), Toma et al. (1999) found an increase in levels of exchangeable $\mathrm{Ca}$ up to $120 \mathrm{~cm}$ after 16 years of $35 \mathrm{Mg} \mathrm{ha}^{-1}$ of P G application in a kaolinitic soil. The levels of exchangeable $\mathrm{Mg}$ were reduced linearly with the PG rates applied from 0 to $40 \mathrm{~cm}$ depth (Figure 3). Leaching of exchangeable 
$\mathrm{Mg}$ from the soil surface resulted in an increase surface of nutrient contentat $60-120 \mathrm{~cm}$ depth after 3.5 years of PG application. According to Zambrosi et al., 2007, the leaching of exchangeable $\mathrm{Mg}$ contents in the soil, with the addition of PG, is facilitated by the formation of the ionic-pair $\mathrm{MgSO}_{4}$. This finding has been also reported in several field studies (Caires et al. 1998; 2004; 2006; 2011b; c; Toma et al., 1999). For example, in the study performed by Toma et al. (1999), the $\mathrm{Mg}^{2+}$ leaching was observed from the 20-60 cm layer to the 100-120 $\mathrm{cm}$ layer, after sixteen years of PG application. The alleviation of soil acidity with dolomitic lime may be a viable alternative to minimize losses of exchangeable Mg caused by PG applications (Caires et al., 2011b).

As the soil in this study presented low acidity, the levels of exchangeable $\mathrm{Al}$ found in the soil were lower than $1 \mathrm{mmol} \mathrm{kg}^{-1}$, and were not influenced by the PG rates (Figure 3). After 3.5 years of the PG application, we did not observe an effect of the treatments on soil exchangeable $\mathrm{K}$ contents, although leaching of $\mathrm{K}^{+}$ was observed in the first years of evaluation (Caires et al., 2011c). Potassium contents were $8.6 \mathrm{mmol} \mathrm{kg}^{-1}$ in the control treatment (without PG addition) and 7.8 mmol $\mathrm{kg}^{-1}$ in the treatment that had received $\mathrm{PG}$ at 12 $\mathrm{t} \mathrm{ha}{ }^{-1}$. K contents were, in average, $5.5 \mathrm{mmol} \mathrm{kg}^{-1}$ at

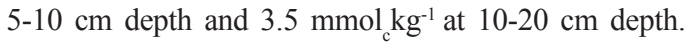
Below the $60 \mathrm{~cm}$ depth, $\mathrm{K}$ contents were lower than 1.0 $\mathrm{mmol}_{\mathrm{c}} \mathrm{kg}^{-1}$.

\subsection{Factors related to sulfate retention}

After thirteen years of PG application at $12 \mathrm{t} \mathrm{ha}^{-1}, 52 \%$ $\left(503.6 \mathrm{mg} \mathrm{kg}^{-1}\right)$ of applied sulfate was recovered in the soil profile $(0-200 \mathrm{~cm})$ in the experiment carried out in Ponta Grossa (Figure 2). However, the remaining sulfate was leached to lower depths. In the experiment carried out in Gurapuava, we recovered $100 \%$ of the sulfate provided by the PG application at $12 \mathrm{ha}^{-1}$ in the soil profile $(0-200 \mathrm{~cm})$. A higher sulfate concentration was found in the $20-60 \mathrm{~cm}$ depth (Figure 3). The sulfate leaching losses may reduce the long-term possibility of maintaining the $\mathrm{S}$ supply of crops in low input farming (Eriksen and Askegaard, 2000), and may also remove cationic nutrients from the root zone. Sulfate losses are a concern in agricultural and economic areas; however, they are not considered as a serious environmental problem. The presence of excessive amounts of sulfate can be a concern in water supplies, because of its cathartic effect upon humans (Jang; Townsend, 2001). Also, it may convert to hydrogen sulfide during some reuse scenarios, causing noticeable odors and tastes.

Table 3 shows soil attributes related to sulfate adsorption. Srem varied from 4.1 to $14.9 \mathrm{mg} \mathrm{L}^{-1}$ in the loamy Oxisol from Ponta Grossa, and from 3.5 to $15 \mathrm{mg} \mathrm{L}^{-1}$ in the clayey Oxisol from Guarapuava. Prem showed a wide variation between soil depths and the two experimental areas, varying from 1.3 to $21.9 \mathrm{mg} \mathrm{L}^{-1}$ in Ponta Grossa, and from 0.1 to $2.5 \mathrm{mg} \mathrm{L}^{-1}$ in Guarapuava (Table 3). Although both Srem and Prem normally present a close correlation with the maximum sulfate adsorption capacity in soils (Alves and Lavorenti, 2004a), Prem showed higher discriminatory capacity of sulfate adsorption in the soil profiles of our study. Based on these results, we selected depths with similar adsorption capacities and fitted adsorption isotherms for both experiments. The data presented a better fit to the Freundlich than to the Langmuir equation (Figure 4), and support the results presented by Bolan et al. (1988) and Alves and Lavorenti (2004b). The adsorption capacity increased with depth in both soils evaluated, and higher adsorption capacity was registered for the clayey Oxisol from Guarapuava. By fitting Langmuir isotherms to the data, we obtained a maximum adsorption of $56.8 \mathrm{mg} \mathrm{kg}^{-1}$ of $\mathrm{SO}_{4}{ }^{2-} \mathrm{S}$ for the loamy Oxisol (Ponta Grossa) and $133.3 \mathrm{mg}$ $\mathrm{kg}^{-1}$ for the clayey Oxisol (Guarapuava) at $0-20 \mathrm{~cm}$ depth. At the lowest depth, we found 217.4 and 384.6 $\mathrm{mg} \mathrm{kg}{ }^{-1}$ for Ponta Grossa and Guarapuava, respectively. These results obtained from this study agree with those previously reported for Prem (Alves and Lavorenti, 2004). Despite the fact that Prem had a higher discriminatory capacity of adsorption, the results must be carefully evaluated, especially when practical implications are envisaged. Since phosphate and sulfate do not present the same mechanism of adsorption (Goldberg, 2010), they can present different behaviors in agricultural and environmental systems. 

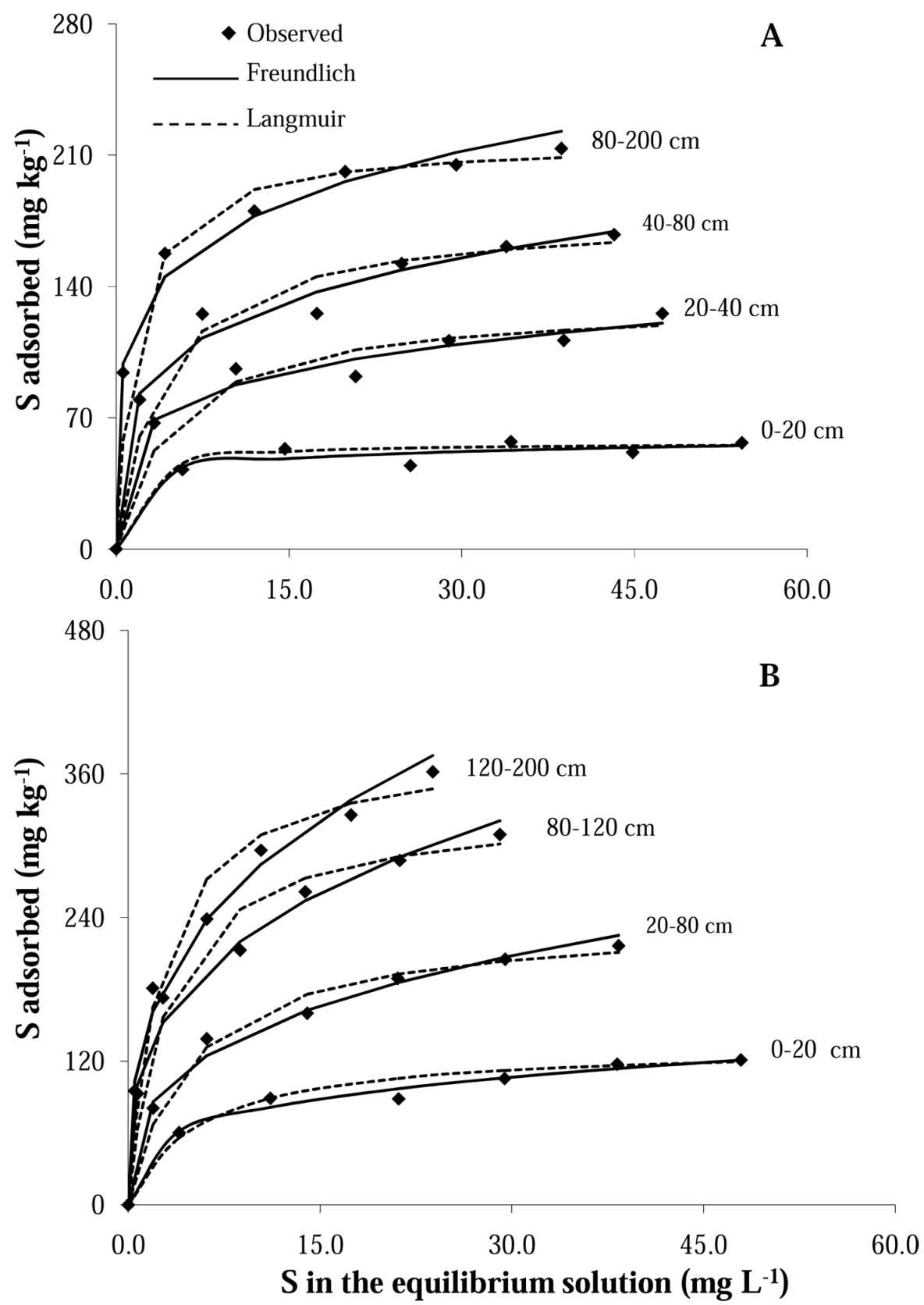

Figure 4. Experimental data of sulfate adsorption for the loamy Oxisol (A) and for the clayey Oxisol (B) at different depths, and adsorption curves drawn according to the Freundlich and Langmuir equations. 
Higher levels of organic $\mathrm{C}$ were observed for the soil surface, and the soil from Guarapuava presented 55\% more organic $\mathrm{C}$ than the soil from Ponta Grossa for all soil profiles evaluated. Higher amounts of organic $\mathrm{C}$ favor sulfate leaching due to the increase in negative charges and repulsion of $\mathrm{SO}_{4}^{2-}-\mathrm{S}$ (Couto et al., 1979). Contents of $\mathrm{Fe}_{\mathrm{d}}, \mathrm{Fe}_{\mathrm{o}}$ and Al- were higher in the Guarapuava soil. In both sites, the $\mathrm{Fe}_{\mathrm{o}} / \mathrm{Fed}$ ratio was lower than 0.07 , which indicates the dominance of crystalline $\mathrm{Fe}$ hydroxides (Schwertmann et al., 1982). Oxalate-soluble Fe and $\mathrm{Al}$ play an important role in sulfate adsorption in highly weathered sub-soils (Alves and Lavorenti, 2004b).

The retention of sulfate in soils is dependent on the nature of the colloidal system, soil $\mathrm{pH}$, the concentration of sulfate and the concentration of other ions in solution. As a consequence, sulfate leaching may be subjected to considerable variation caused by differences in soil attributes or climatic conditions, and by differences in agricultural management (Eriksen and Askegaard, 2000).

The $\mathrm{pH} \mathrm{NaF}$ values ranged from 9.5 to 10.6 for Ponta Grossa and from 10.3 to 11.0 for Guarapuava, suggesting that $\mathrm{F}^{-}$replaces $\mathrm{OH}^{-}$from the surface of soil colloids, thus increasing the $\mathrm{pH}$ value. However, $\mathrm{pH} \mathrm{NaF}$ also showed a small discriminatory capacity for both soils, when compared to Prem, supporting the results previously reported by Alves and Lavorenti (2004a).

Even for soils with a marked capacity to retain sulfate, the strength of the retention seems to be weak. Chao et al. (1962) found that the adsorbed sulfate could be removed by repeated extraction with water. Since almost half of the applied sulfate was already leached to depths lower than $200 \mathrm{~cm}$ in the experiment conducted in Ponta Grossa, the sulfate extracted by calcium phosphate represents the soluble portion plus the retained $\mathrm{SO}_{4}{ }^{2-}$-S remaining in the profile. By correlating the amounts of sulfate extracted by calcium sulfate and some soil attributes (Table 4), we verified that $\mathrm{Fe}_{\mathrm{d}}, \mathrm{Fe}_{\mathrm{d}}-\mathrm{Fe}_{\mathrm{o}}$ and $\mathrm{pH} \mathrm{NaF}$ had positive correlations with $\mathrm{SO}_{4}^{2-}-\mathrm{S}$, while Srem, organic $\mathrm{C}$ and Prem were negatively correlated. We obtained lower coefficients of correlation for the Oxisol of Guarapuava (Table 5) since the PG was applied 3.5 years ago, and it is still coming down in the profile. Moreover, we still observed high correlation coefficients between $\mathrm{SO}_{4}{ }^{2-}-\mathrm{S}$ and $\mathrm{pH}$ measured in $\mathrm{NaF}$, organic $\mathrm{C}$ and Srem.

\subsection{Crop grain yields}

Despite the decrease in exchangeable $\mathrm{Al}$ and the increase in exchangeable $\mathrm{Ca}$ contents after long-term applications of lime and PG (Figure 2), there was no significant increase in grain yield of cereal crops (maize + wheat) in Ponta Grossa (Figure 5). Many field trials conducted under NTS have shown increases in cereal crop grain yields with applications of lime (Ernani et al., 2002; Caires et al., 2005; 2008) and PG (Toma et al., 1999; Farina et al., 2000a; Caires et al., 2011a;b; c).

In our study, both crops achieved good grain yields; the average was of 9,016 kg ha-1 for maize and 2,553 $\mathrm{kg} \mathrm{ha}^{-1}$ for wheat. Based on the limited rainfall in December 2008 (Figure 1), we would expect to see positive effects of lime and PG applications on maize grain yields. However that did not occur. Water deficit usually potentiates the positive effects of lime and PG applications, especially when cereals are cropped (Caires et al., 2008). Some authors have reported high crop grain yield in acid soils, under NTS even in the absence of lime (Brown et al., 2008; Caires et al., 2005; 2011a). Thus, the large grain yield found in acidic conditions is attributed to the lower concentration of toxic species of Al, and to the higher concentration of Al complexed with organic matter (Brown et al., 2008; Alleoni et al., 2010). Another possible explanation for the absence of crop response, is the short range of $\mathrm{pH}$ values (between 3.9 and 4.7), considering that the amendments were applied to the soil in 1993, and it did not longer had such significant effects. In a previous study carried out by Joris (2010), under similar conditions to those of this study, he observed the highest maize grain yield at $\mathrm{pH}$ of $6.1\left(0.01 \mathrm{M} \mathrm{CaCl}_{2}\right)$. Ernani et al. (2002) observed that $\mathrm{pH}$ values above those required for $\mathrm{Al}$ neutralization have also contributed to the increase of maize yield. Increasing the PG rate applied to the soil surface led to a linear increase of cereal crop grain yields (maize+triticale) in Guarapuava (Figure 6). Based on the regression equation obtained, PG application at $12 \mathrm{tha}^{-1}$ increased grain yield by $12 \%$. 
Table 4. Pearson Product Moment Correlation between the $\mathrm{SO}_{4}{ }^{2-}-\mathrm{S}$ in the soil profile and soil attributes related to $\mathrm{S}$ retention $(\mathrm{n}=12)$ for Ponta Grossa.

\begin{tabular}{cccccccccc}
\hline & $\mathrm{SO}_{4}-\mathrm{S}$ & Organic $\mathrm{C}$ & $\mathrm{Fe}_{\mathrm{d}}$ & $\mathrm{Fe}_{\mathrm{o}}$ & $\mathrm{Al}_{\mathrm{o}}$ & $\mathrm{Fe}_{\mathrm{d}}-\mathrm{Fe}_{\mathrm{o}}$ & $\mathrm{pH}_{\mathrm{NaF}}$ & Prem & Srem \\
\hline $\mathrm{SO}_{4}{ }^{2 \cdot}$ & - & $-0.86^{* *}$ & $0.90^{* *}$ & $-0.39 \mathrm{~ns}$ & $0.34 \mathrm{nn}$ & $0.90^{* *}$ & $0.84^{* *}$ & $-0.84^{* *}$ & $-0.89^{* *}$ \\
Organic C & - & $-0.96^{* *}$ & $0.56 \mathrm{~ns}$ & $-0.46 \mathrm{~ns}$ & $-0.96^{* *}$ & $-0.98^{* *}$ & $0.99^{* *}$ & $0.92^{* *}$ \\
$\mathrm{Fe}_{\mathrm{d}}$ & & & - & $-0.62^{*}$ & $0.53 \mathrm{~ns}$ & $0.99^{* *}$ & $0.97^{* *}$ & $-0.97^{* *}$ & $-0.92^{* *}$ \\
$\mathrm{Fe}_{\mathrm{o}}$ & & & & - & $-0.51 \mathrm{~ns}$ & $-0.63^{*}$ & $-0.61^{*}$ & $0.57 \mathrm{~ns}$ & $0.48 \mathrm{~ns}$ \\
$\mathrm{Al}_{\mathrm{o}}$ & & & & & - & $0.53 \mathrm{~ns}$ & $-0.22 \mathrm{~ns}$ & $-0.43 \mathrm{~ns}$ & $0.58^{*}$ \\
$\mathrm{Fe}_{\mathrm{d}}-\mathrm{Fe}_{\mathrm{o}}$ & & & & & & - & $0.97^{* *}$ & $-0.97^{* *}$ & $-0.91^{* *}$ \\
$\mathrm{pH}_{\mathrm{NaF}}$ & & & & & & & - & $-0.97^{* *}$ & $-0.86^{* *}$ \\
Prem & & & & & & & - & $0.96^{* *}$ \\
Srem & & & & & & & & - \\
\hline
\end{tabular}

Table 5. Pearson Product Moment Correlation between the $\mathrm{SO}_{4}{ }^{2-}$ in the soil profile andsoil attributes related to $\mathrm{S}$ retention( $\mathrm{n}=12)$ for Guarapuava.

\begin{tabular}{|c|c|c|c|c|c|c|c|c|c|}
\hline & $\mathrm{SO}_{4}{ }^{2-}$ & Organic C & $\mathrm{Fe}_{\mathrm{d}}$ & $\mathrm{Fe}_{\mathbf{0}}$ & $\mathrm{Al}_{0}$ & $\mathrm{Fe}_{\mathrm{d}_{\mathrm{d}}-\mathrm{Fe}_{\mathrm{o}}}$ & $\mathrm{pH}_{\mathrm{NaF}}$ & P-rem & S-rem \\
\hline $\mathrm{SO}_{4}-\mathrm{S}$ & - & $-0.62^{*}$ & $-0.09 n s$ & $0.45 \mathrm{~ns}$ & $0.54 \mathrm{~ns}$ & $-0.11 \mathrm{~ns}$ & $0.89^{* *}$ & $0.66^{*}$ & $-0.75^{*}$ \\
\hline Organic C & & - & $-0.42 n s$ & $-0.88^{* *}$ & $0.22 \mathrm{~ns}$ & $-0.37 \mathrm{~ns}$ & $-0.86^{* *}$ & $0.99 * *$ & $0.96^{* *}$ \\
\hline$F_{e_{d}}$ & & & . & $0.33 \mathrm{~ns}$ & $-0.64 *$ & $0.99 * *$ & $0.00 \mathrm{~ns}$ & $-0.32 n s$ & $-0.26 n s$ \\
\hline $\mathrm{Fe}_{\mathrm{o}}$ & & & & - & $-0.18 n s$ & $0.27 \mathrm{~ns}$ & $0.70^{* *}$ & $-0.87^{* *}$ & $-0.90^{* *}$ \\
\hline $\mathrm{Al}_{\mathrm{o}}$ & & & & & - & $-0.64^{*}$ & $0.24 \mathrm{~ns}$ & $0.16 \mathrm{~ns}$ & $0.03 \mathrm{~ns}$ \\
\hline $\mathrm{Fe}_{\mathrm{d}^{-}}-\mathbf{F} \mathbf{e}_{\mathrm{o}}$ & & & & & & - & $-0.03 n s$ & $-0.27 n s$ & $-0.21 \mathrm{~ns}$ \\
\hline $\mathbf{p H} \mathrm{NaF}$ & & & & & & & - & $-0.89 * *$ & $-0.92^{* *}$ \\
\hline Prem & & & & & & & & - & $0.97^{* *}$ \\
\hline Srem & & & & & & & & & - \\
\hline
\end{tabular}

Positive responses of PG application on the yield of cereal crops, especially maize, have been obtained in several other studies conducted under diverse soil and weather conditions (Raij et al., 1998; Toma et al., 1999; Farina et al., 2000a; Caires et al., 1999; 2004; 2011a;c). In our study, where the soil had high exchangeable $\mathrm{Ca}$ levels and low exchangeable Al levels throughout the profile, he increases in grain yield due to the sub-soil improvement prompt by $\mathrm{PG}$ addition was an unexpected result.
Unlike the region of Ponta Grossa, no rainfall limitation was observed during crop growth (Figure 1). In our experiment, the increase in grain yield could be explained by the changes in the topsoil chemical attributes, which was due to PG application. The attributes most correlated to crop grain yield were (i) increases of $\mathrm{SO}_{4}{ }^{2-}-\mathrm{S}$ content; (ii) increases of exchangeable $\mathrm{Ca}$ content and $\mathrm{Ca} / \mathrm{Mg}$ ratio; and (iii) decreases of exchangeable $\mathrm{Mg}$ and $\mathrm{K}$ contents (Table 6). Potassium data is not discussed here, because we did not observe effects of the soil 


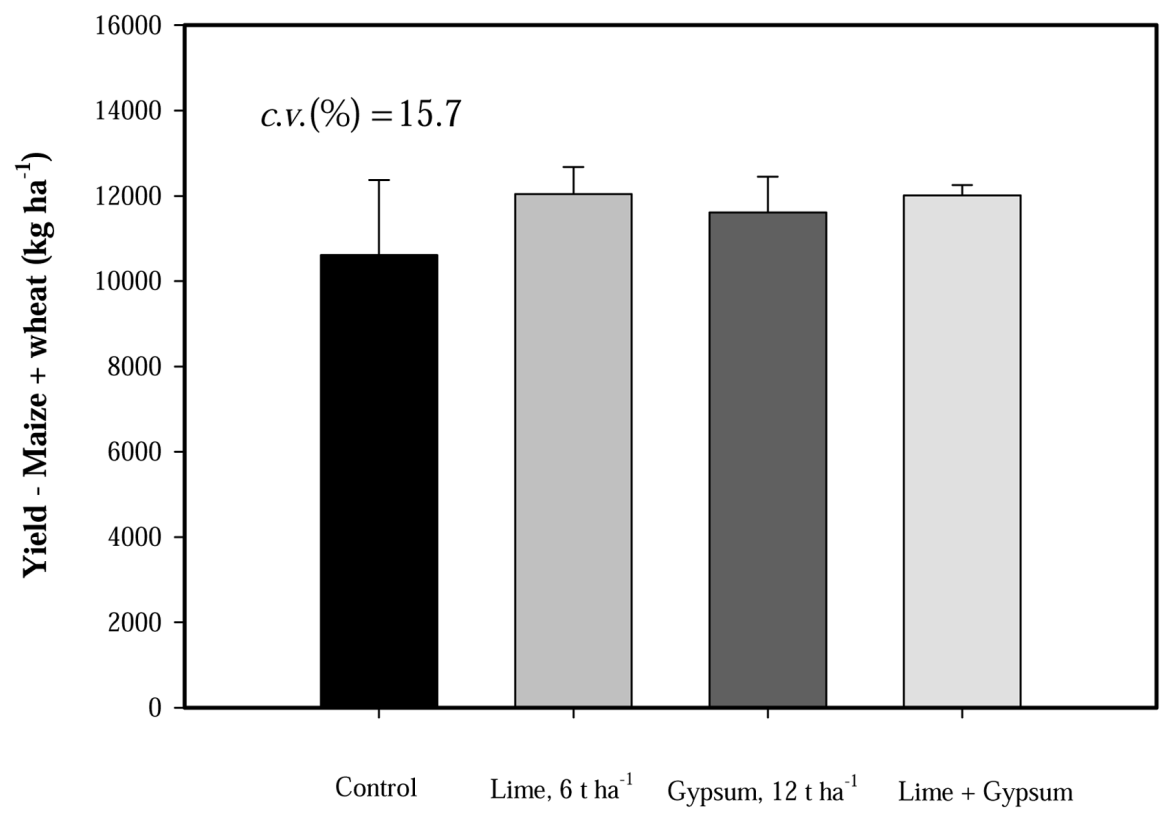

Figure 5. Accumulated yield (maize+wheat), grown in 2008-2009 in response to lime and phosphogypsum application in 1993 in Ponta Grossa.

conditioner on this ion after 3.5 years of PG application. However, intense leaching of $\mathrm{K}$ was registered in the first years after application of $\mathrm{PG}$ (Caires et al., 2011c).

The attribute that most contributed to explain the increases of cereal yield occurred at $0-20 \mathrm{~cm}$ depth. However, effects of PG were also observed at deeper soil layers.

Higher correlation coefficients were verified for $\mathrm{Ca}$ and $\mathrm{Mg}$ contents, which were extracted by $\mathrm{KCl}$, and for $\mathrm{SO}_{4}{ }^{2-}-\mathrm{S}$ extracted by calcium phosphate.
The data presented in this study support the findings previously discussed by Caires et al. (2011 b; c). For example, these authors reported that an increase of grain yield observed for cereal crops grown in soils without limitations imposed by acidic conditions are mainly related to the supply of $\mathrm{Ca}$ and $\mathrm{S}$ to the plants. 


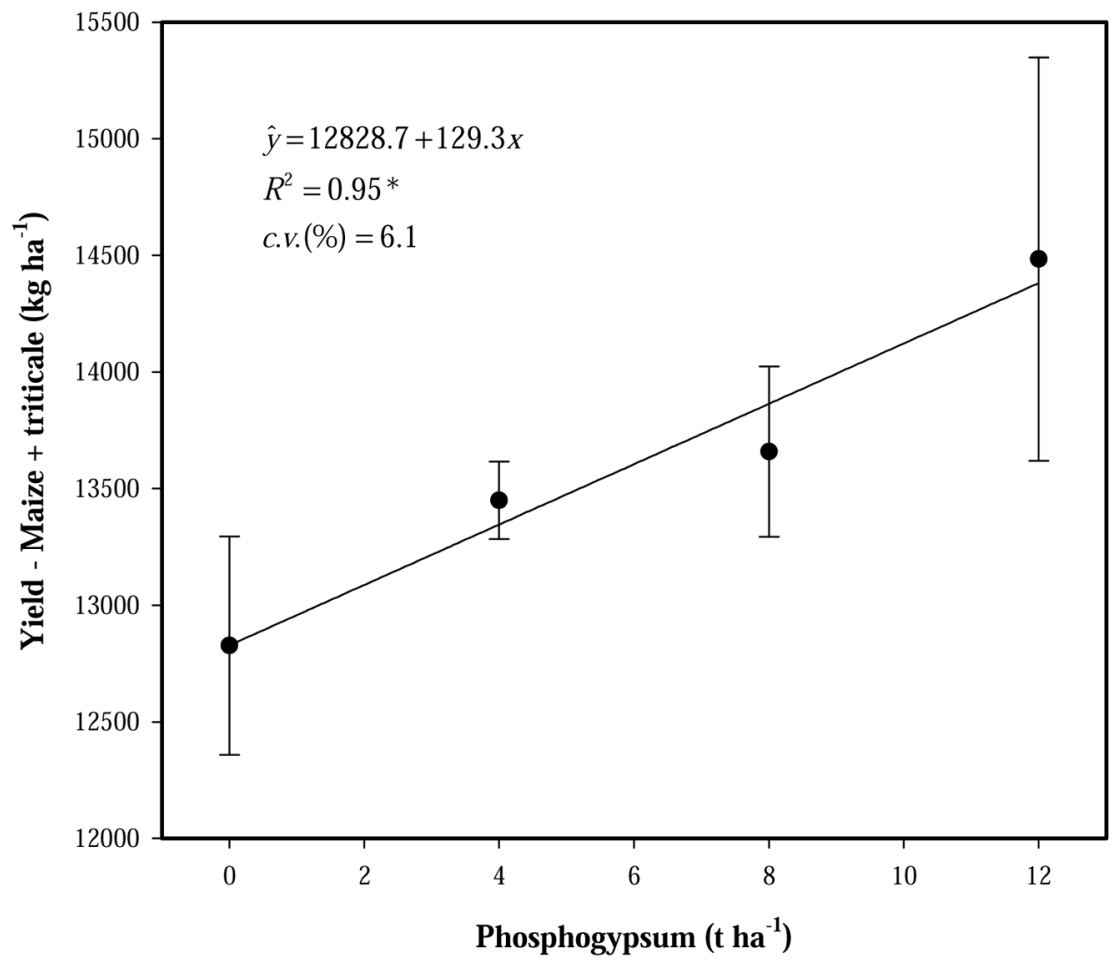

Figure 6 . Accumulated yield (maize+triticale), grown in 2008-2009 in response to phosphogypsum rates applied tothe soil surface in 2005 in Guarapuava.

Table 6. Pearson Product Moment Correlation between the accumulated cereal yield and soil chemical attributes at different depths $(\mathrm{n}=16)$.

\begin{tabular}{|c|c|c|c|c|c|c|c|c|}
\hline $\begin{array}{c}\text { Depth } \\
\text { (cm) }\end{array}$ & $\begin{array}{c}\mathrm{SO}_{4}{ }^{2-}-\mathrm{S} \\
\mathrm{Ca}\left(\mathrm{HPO}_{4}\right)_{2}\end{array}$ & $\begin{array}{c}\mathrm{SO}_{4}{ }^{2-}-\mathrm{S} \\
\mathrm{NH}_{4} \mathrm{OAC}\end{array}$ & $\begin{array}{l}\mathrm{Ca}^{2+} \\
\mathrm{KCI}\end{array}$ & $\begin{array}{l}\mathrm{Ca}^{2+} \\
\text { Resin }\end{array}$ & $\begin{array}{l}\mathrm{Mg}^{2+} \\
\mathrm{KCl}\end{array}$ & $\begin{array}{l}\mathrm{Mg}^{2+} \\
\text { Resin }\end{array}$ & $\begin{array}{c}\mathrm{K}^{+} \\
\text {Mehlich- 1 }\end{array}$ & $\begin{array}{c}\mathrm{Ca} / \mathrm{Mg} \\
\mathrm{KCl}\end{array}$ \\
\hline $0-5$ & $0.69^{* *}$ & $0.66^{* *}$ & $0.60^{*}$ & $0.66^{* *}$ & $-0.42 n s$ & $-0.31 \mathrm{~ns}$ & $-0.50^{*}$ & $0.52^{*}$ \\
\hline $5-10$ & $0.69^{* *}$ & $0.79 * *$ & $0.66^{* *}$ & $0.23 \mathrm{~ns}$ & $-0.43 n s$ & $-0.35 \mathrm{~ns}$ & $-0.42 \mathrm{~ns}$ & $0.59 *$ \\
\hline $10-20$ & $0.63^{* *}$ & $0.57 *$ & $0.65^{* *}$ & $0.48 \mathrm{~ns}$ & $-0.46 n s$ & $-0.30 \mathrm{~ns}$ & $-0.62^{* *}$ & $0.57^{*}$ \\
\hline $20-40$ & $0.29 \mathrm{~ns}$ & $0.32 \mathrm{~ns}$ & $0.39 \mathrm{~ns}$ & $0.41 \mathrm{~ns}$ & $-0.14 n s$ & $-0.20 \mathrm{~ns}$ & $-0.46 \mathrm{~ns}$ & $0.09 \mathrm{~ns}$ \\
\hline $40-60$ & $0.39 \mathrm{~ns}$ & $0.43 \mathrm{~ns}$ & $0.48 \mathrm{~ns}$ & $0.56^{*}$ & $0.14 \mathrm{~ns}$ & $0.36 \mathrm{~ns}$ & $0.27 \mathrm{~ns}$ & $0.20 \mathrm{~ns}$ \\
\hline $60-80$ & $0.46 \mathrm{~ns}$ & $0.46 \mathrm{~ns}$ & $0.40 \mathrm{~ns}$ & $0.31 \mathrm{~ns}$ & $0.70^{* *}$ & $0.46 \mathrm{~ns}$ & $-0.13 n s$ & $0.01 \mathrm{~ns}$ \\
\hline $80-100$ & $0.14 \mathrm{~ns}$ & $0.54^{*}$ & $-0.06 n s$ & $0.02 \mathrm{~ns}$ & $0.21 \mathrm{~ns}$ & $0.19 \mathrm{~ns}$ & $-0.27 n s$ & $-0.30 \mathrm{~ns}$ \\
\hline $100-120$ & $0.21 \mathrm{~ns}$ & $0.28 \mathrm{~ns}$ & $-0.31 \mathrm{~ns}$ & $0.06 \mathrm{~ns}$ & $0.15 \mathrm{~ns}$ & $0.22 \mathrm{~ns}$ & $-0.22 \mathrm{~ns}$ & $-0.38 \mathrm{~ns}$ \\
\hline $120-140$ & $0.35 \mathrm{~ns}$ & $0.41 \mathrm{~ns}$ & $0.47 \mathrm{~ns}$ & $0.30 \mathrm{~ns}$ & $0.49 \mathrm{~ns}$ & $0.53^{*}$ & $-0.18 n s$ & $0.12 \mathrm{~ns}$ \\
\hline $140-160$ & $0.26 \mathrm{~ns}$ & $0.26 \mathrm{~ns}$ & $0.51 *$ & $0.38 \mathrm{~ns}$ & $0.46 \mathrm{~ns}$ & $0.24 \mathrm{~ns}$ & $-0.15 n s$ & $0.16 \mathrm{~ns}$ \\
\hline $160-180$ & $0.24 \mathrm{~ns}$ & $0.40 \mathrm{~ns}$ & $0.05 \mathrm{~ns}$ & $0.04 \mathrm{~ns}$ & $0.26 \mathrm{~ns}$ & $0.24 \mathrm{~ns}$ & $-0.30 \mathrm{~ns}$ & $-0.03 \mathrm{~ns}$ \\
\hline $180-200$ & $0.21 \mathrm{~ns}$ & $0.27 \mathrm{~ns}$ & $0.50 \mathrm{~ns}$ & $0.59 *$ & $0.54^{*}$ & $0.33 \mathrm{~ns}$ & $-0.39 n s$ & $0.15 \mathrm{~ns}$ \\
\hline $0-20$ & $0.67 * *$ & $0.63^{* *}$ & $0.67 * *$ & $0.53^{*}$ & $-0.45 n s$ & $-0.33 n s$ & $-0.59 *$ & $0.58^{*}$ \\
\hline
\end{tabular}




\section{Conclusions}

Applications of lime and phosphogypsum to the soil surface under no-till conditions provided long-term effects, ameliorating the root environment of plants. The effects of surface-applied lime reducing the soil acidity and increasing the exchangeable $\mathrm{Ca}$ and $\mathrm{Mg}$ contents were visible up to $80 \mathrm{~cm}$ depth, while the effects of phosphogypsum increasing $\mathrm{Ca}$ and $\mathrm{SO}_{4}^{2-}-\mathrm{S}$ contents were more pronounced at deeper soil layers. Sulfate distribution in the soil profile was mostly correlated with $\mathrm{Fe}_{\mathrm{d}}$ and $\mathrm{Fe}_{\mathrm{d}}-\mathrm{Fe}_{\mathrm{o}}$. No differences were found in maize + wheat yields in Ponta Grossa after long-term phosphogypsum application (15 years). In Guarapuava, the medium-term PG effects (3.5 years) showed a rapid $\mathrm{SO}_{4}^{2-}-\mathrm{S}$ movement to the sub-soil, despite the soil higher adsorption capacity of sulfate. Surface-applied PG had positive benefits on maize + triticale yields due to increased $\mathrm{Ca}$ and $\mathrm{SO}_{4}{ }^{2-}-\mathrm{S}$ availability for the plants. Although the soils showed different capacities of sulfate adsorption, and were evaluated at different times, the crop responses to PG application under NTS were associated not only to the improvement of sub-soil conditions, but could also be related to the improvement of the soil chemical conditions of the soil surface layers.

\section{Acknowledgements}

This research was supported by $\mathrm{CNPq}$ (Conselho Nacional de Desenvolvimento Científico e Tecnológico), a Brazilian agency that supports scientific development. It was also supported by CAPES (Coordenação de Aperfeiçoamento de Pessoal de Nível Superior), a Brazilian agency that supports theexpansion and consolidation of postgraduate research. The authors would like to express their gratitude to Adriano Haliski, Fernando Garbuio, Gabriel Barth, Helio Joris, Julius Blum and Valter Asami for their help during the field work and to Alexys Boim for substantial help with laboratory work.

\section{References}

Alleoni, L.R.F., Cambri, M.A., Caires, E.F. Garbuio, F. J. 2010. Acidity and aluminum speciation as affected by surface liming in tropical no-till soils. Soil Science Society of America Journal. 74, 10101017.

Alvarez, V.H., Novais, R.F., Dias, L.E. Oliveira, J.A. 2000. Determinação e uso do fósforo remanescente. Boletim Informativo da Sociedade Brasileira de Ciência do Solo, SBCS, Viçosa. 25,27-32

Alvarez, V.H., Novais, R.F., Neves, J.C.L.Barros, N.F. 1983. Níveis críticos de enxofre em solos de cerrado para crescimento de mudas de eucalipto. In: Congresso Brasileiro de Ciência do Solo, SBCS, Curitiba pp. 164-165.

Alves, M.E., Lavorenti, A. 2004a. Remaining phosphorus and sodium fluoride $\mathrm{pH}$ in soils with different clay contents and clay mineralogy. Pesquisa Agropecuária Brasileira. 39, 241-246.

Alves, M.E., Lavorenti, A. 2004b. Sulfate adsorption and its relationships with properties of representative soils of the São Paulo State, Brazil. Geoderma.118, 89-99.

Amaral, A.S., Anghinoni, I., Henrichis, R., Bertol, I. 2004. Movement of lime particles in the profile of an Inceptisol under no-tillage. Revista Brasileira de Ciência do Solo. 28,359-367.

Beaton, J.D., Burns, G.R. ,Platou, J. 1968. Determination of sulfur in soils and plant material. Technical Bulletin Number 14, The Sulfur Institute, 56p.

Blum, J., Caires, E.F., Ayub, R.A., Fonseca, A.,Sozim, M., Fauate, M. 2011. Soil chemical attributes and grape yield as affected by gypsum application in Southern Brazil. Communications in Soil Science and Plant Analysis. 42, 1434-1443. 
Bolan, N.S., Syers, J.K., Tilman, R.W., Scotter, D.R. 1988. Effect of liming and phosphate additions on sulphate leaching in soils. Journal of Soil Science. 39, 493-504.

Bolland, M.D.A., Gilkes, R.J., Brennan, R.F. and Allen, D.G. 1996. Comparison of seven phosphorus sorption indices. Australian Journal of Soil Research. 34, 81-89.

Brazil. Fundação Instituto Brasileiro de Geografia e Estatística - IBGE. Levantamento Sistemático da Produção Agrícola. http://www.ibge.gov.br/ home/estatistica/indicadores/agropecuaria/lspa/ 1spa_201010.pdf. Accessed on December 10th, 2011.

Brown, T.T., Koenig, R.T., Huggins, D.R., Harsh, J.B. and Rossi, R.E. 2008. Lime effects on soil acidity, crop yield, and aluminum chemistry in directseeded cropping systems. Soil Science Society of America Journa. 72, 634-640.

Caires, E.F., Alleoni, L.R.F., Cambri, M.A. Barth, G. 2005. Surface application of lime for crop grain productionunder a no-till system. Agronomy Journal. 97, 791-798.

Caires, E.F.; Chueiri, W.A.; Madruga, F.E. Figueiredo, A. 1998. Alterações de características químicas do solo e resposta da soja ao calcário e gesso aplicados na superfície em sistema de cultivo sem preparo do solo. Revista Brasileira de Ciência do Solo. 22, 27-34.

Caires, E.F.; Fonseca, A.F.; Feldhaus, I.C.; Blum, J. 2001. Crescimento radicular e nutrição da soja cultivada no sistema plantio direto em resposta ao calcário e gesso na superfície. Revista Brasileira de Ciência do Solo. 25, 1029-1040.

Caires, E.F., Churka, S., Garbuio, F.J., Ferrari, R.A. Morgano, M.A. 2006. Soybean yield and quality as a function of lime and gypsum applications. Scientia Agricola. 63, 370-379.
Caires, E.F., Garbuio, F.J., Churka, S., Barth, G. Corrêa, J.C.L. 2008. Effects of soilacidity amelioration by surface liming on no-till corn, soybean and wheat root growth and yield. European Journal of Agronomy. 28, 57-64.

Caires, E.F., Garbuio, F.J., Churka, S. Joris, H.A.W. 2011a. Use of gypsum for crop grain production under a subtropical no-till cropping system. Agronomy Journal. 103, 1804-1814.

Caires, E.F., Kusman, M.T., Barth, G., Garbuio, F.J. Padilha, J.M. 2004. Changes in soil chemical properties and corn response to lime and gypsum applications. Revista Brasileira de Ciência do Solo. 28, 125-136.

Caires, E.F., Joris, H.A.W., Churka, S. 2011b. Longterm effects of lime and gypsum additions on no-till corn and soybean yield and soil chemical properties in southern Brazil. Soil. Use and Management. 27, 45-53.

Caires, E.F., Maschietto, E.H.G., Garbuio, F.J., Churka, S., Joris, H.A.W. 2011c. Surface application of gypsum in low acidic Oxisol under no-till cropping system. Scientia Agricola. 68, 209-216.

Caires, E.F., Fonseca, A.F., Mendes, J., Chueiri, W.A. Madruga, E.F. 1999. Corn, wheat and soybean yields as a function of the changes in soil chemical characteristics due to surface application of lime and gypsum under a no-tillage system. Revista Brasileira de Ciência do Solo. 23, 315-327.

Camargo, O.A., Moniz, A.C., Jorge, J.A. Valadares, J.M.A.S. 1986. Methods of soil chemical, mineralogical and physical analyses. Technical Bulletin 106 Agronomic Institute of Sao Paulo State, Campinas.

Chao, T.T., Harward, M.E. ,Fang, S.C. 1962. Adsorption and desorption phenomena of sulfate ions in soils. Soil Science Society of America Proceedings. 26, 234-237. 
Chao, T.T., Harward, M.E., Fang, S.C. 1963. Cationic effects on sulfate adsorption by soils. Soil Science Society of America Proceedings. 27,3 5-38.

Cichota, R., Vogeler, I., Bolan, N.S. Clothier, B. 2007. Simultaneous adsorption of calcium and sulfate and its effect on their movement. Soil Science Society of America Journal. 71, 703710 .

Couto, W., Lathell, D.J., Bouldin, J.R. 1979. Sulfate adsorption by two oxisols and alfisols of the tropics. Soil Science . 127, 108-116.

Ensminger, L.E. 1954. Some factors affecting the adsorption of sulfates by Alabama soils. Soil Science Society of America Proceedings. 18, 259-264.

Eriksen, J., Askegaard, M. 2000. Sulphate leaching in an organic crop rotation on sandy soil in Denmark. Agriculture, Ecosystem and Environment. 78, 107-114.

Ernani, P.R., Bayer, C, Maestri, L. 2002. Corn yield as affected by liming and tillage system on an acid Brazilian Oxisol. Agronomy Journal. 94, 305-309.

Farina, M.P.W., Channon, P., Thibaud, G.R. 2000a. A comparison of strategies for amelioration subsoil acidity: I Long-term growth effects. Soil Science Society of America Journal. 64, 646-651.

Farina, M.P.W., Channon, P. Thibaud, G.R. 2000b. A comparison of strategies for amelioration subsoil acidity: II Long-term soil effects. Soil Science Society of America Journal. 64,652-658.

Fox, R.L., Olson, R.A., Rhoades, H.F. 1964. Evaluating the sulfur status of soil by plant and soil test.Soil Science Society of America Proceedings. 28, 243-246.
Franchini, J.C., Hoffmann-Campo, C.B., Torres, E., Miyazawa, M., Pavan, M.A. 2003. Organic composition of green manures during growth and its effect on cation mobilization in an acid Oxisol. Communications in Soil Science and Plant Analysis. 34, 2045-2058.

Garbuio, F.J., Jones, D.L., Alleoni, L.R.F., Murphy, D.V., Caires, E.F. 2011. Carbon and nitrogen dynamics in an Oxisol as affected by liming and crop residues under no-till. Soil Science Society of America Journal. 75, 1723-1730.

Gee, G.W., Or, D. 2002. Particle-size analysis. In: J. H. Dane and G.C. Toop (eds.). Methods of soil analysis: Physical methods. Soil Science Society of America, Madison, Wisconsin, pp. 255-293.

Goldberg, S. 2010. Competitive adsorption of molybdenum in the presence of phosphorus or sulfur on gibbsite. Soil Science. 175, 105-110.

Hue, N.V., Adams, F., Evans, C.E. 1985. Sulfate retention by an acid BE horizon of an Ultisol. Soil Science Society of America Journal. 49, 1196-1200.

Jang, Y., Townsend, T. 2001. Sulfate leaching from recovered construction and demolition debris fines. Advances in Environmental Research. 5, 203-217.

Joris, H.A.W. 2010. Surface liming, soil moisture and corn response under no-till system.Masters Dissertation, University of Ponta Grossa, Brazil. 89p.

Juo, A.S.R., Dabiri, A., Franzluebbers, K. 1995. Acidification of a kaolinitic Alfisol under continuous cropping with nitrogen fertilization in West Africa. Plant and Soil. 171, 245-253.

Kämpf, N., Schwertmann, U. 1983. Relationship between iron oxides and soil color in kaolinitic soils of Rio Grande do Sul. Revista.Brasileira de Ciência do Solo. 7, 27-31. 
Loeppert, R.H., Inskeep, W.P. 1996. Iron. In: D.L. Sparks, A.L. Page, P.A. Helmke, R.H. Loeppert, P.N. Soltanpour, M.A. Tabatabai, C.T. Johnston, M.E. Sumner (eds). Methods of soil analysis: Chemical methods eds. Soil Science Society of America, Madison, Wisconsin, pp. 639-664.

Mehra, O.P., Jackson, M.L. 1960. Iron oxide removal from soils and clays by adithionite-citrate system buffered with sodium bicarbonate. Clays and Clay Minerals. 7, 317-327.

Mekaru, T., Uehara, G. 1972. Anion adsorption in ferruginous tropical soils. Soil Science Society of America Proceedings. 36, 296-300.

Miyazawa, M., Pavan, M.A., Franchini, J.C. 2002. Evaluation of plant residues on the mobility of surface applied lime. Brazilian Archives of Biology and Technology. 45, 251-256.

Oates, K.M., Caldwell, A.G. 1985. Use of by-product gypsum to alleviate soil acidity. SoilScience Society of America Journal. 49, 915-918.

Raij, B., van, Furlani, P.R., Quaggio, J.A., Pettinelli Jr., A. 1998. Gesso na produção de cultivares de milho com tolerância diferencial a alumínio em três níveis de calagem. Revista Brasileira de Ciência do Solo. 22, 101-108.

Reeve, N.G., Sumner, M.E. 1972. Amelioration of subsoil acidity in a Natal Oxisol by leaching of surfaceapplied amendments. Agrochemophysica. 4, 1-6.

Rheinheimer, D.S., Alvarez, J.W.R., Osório Filho, B.D., Silva, L.S., Bortoluzzi, E.C. 2005. Resposta de culturas à aplicação de enxofre e a teores de sulfato num solo de textura arenosa sob plantio direta. Ciência Rural. 35, 562-569.

Ritchey, K.D., Souza, D.M.G., Costa, U.F. 1980. Calcium leaching to increase rooting depth in a Brazilian savanna Oxisol. Agronomy Journal. 72, 40-44.
Ritchey, K.D., Silva, J.E. Costa, U.F. 1982. Calcium deficiency in clayey B horizons of savannah Oxisols. Soil Science. 133, 378-382.

Schwertmann, U., Schulze, D.G., Murad, E. 1982. Identification of ferrihydrite in soils by dissolution kinetics, differential X-ray diffraction and Mössbauer spectroscopy. Soil Science Society of America Journal. 46, 869-875.

Singh, B., Gilkes, R.J. 1991. Phosphorus sorption in relation to soil properties for the major soil types of south Western Australia. Australian Journal of Soil Research. 29, 603-618.

Six, J., Elliot, E.T., Paustian, K. 1999. Aggregate and soil organic matter dynamic under conventional and no-tillage systems. Soil Science Society of America Journal. 63, 1350-1358.

Soratto, R.P., Crusciol, C. 2008. Dolomite and phosphogypsum surface application effects on annual crops nutrition and yield. Agronomy Journal. 100, 261-269.

Sumner, M.E., Shahandeh, H., Bouton, J., Hammel, J. 1986. Amelioration of an acid soil profile through deep liming and surface application of gypsum.Soil Science Society of America Journal. 50, 1254-1258.

Toma, M., Sumner, M.E., Weeks, G., Saigusa, M. 1999. Long term effects of gypsum on crop yield and subsoil chemical properties. Soil Science Society of America Journal. 39, 891-895.

Zambrosi, F.C.B., Alleoni, L.R.F., Caires, E.F. 2007. Nutrient concentration in soil water extracts and soybean nutrition in response to lime and gypsum applications to an acid Oxisol under no-till system. Nutrient Cycling in Agroecosystems. 79, 169-179.

Zhang, G.Y., Yu, T.R. 1997. Coordination adsorption of anions. In: T.R. Yu (ed). Chemistry of variable charge soils. Oxford University Press, New York, New York, pp. 175-218. 